\title{
Diversity oriented syntheses of fused pyrimidines designed as potential antifolates $\uparrow$
}

\author{
Colin L. Gibson, ${ }^{a}$ Judith K. Huggan, ${ }^{a}$ Alan Kennedy, ${ }^{a}$ Lionel Kiefer, ${ }^{a}$ Jeong Hwan Lee, ${ }^{a}$ Colin J. Suckling, $* a$ \\ Carol Clements, ${ }^{b}$ Alan L. Harvey, ${ }^{b}$ William N. Hunter ${ }^{c}$ and Lindsay B. Tulloch ${ }^{c}$
}

\author{
Received 16th October 2008, Accepted 30th January 2009 \\ First published as an Advance Article on the web 6th March 2009 \\ DOI: 10.1039/b818339b
}

\begin{abstract}
Diversity oriented syntheses of some furo[2,3- $d]$ pyrimidines and pyrrolo[2,3- $d]$ pyrimidines related to folate, guanine, and diaminopyrimidine-containing drugs have been developed for the preparation of potential anti-infective and anticancer compounds. Amide couplings and Suzuki couplings on the basic heterocyclic templates were used, in the latter case yields being especially high using aromatic trifluoroborates as the coupling partner. A new ring synthesis of 6-aryl-substituted deazaguanines bearing 2-alkylthio groups has been developed using Michael addition of substituted nitrostyrenes. Diversity at C-2 has been introduced by oxidation and substitution with a range of amino nucleophiles. The chemical reactivity of these pyrrolopyrimidines with respect to both electrophilic substitution in ring synthesis and nucleophilic substitution for diversity is discussed. Several compounds were found to inhibit pteridine reductases from the protozoan parasites Trypanosoma brucei and Leishmania major at the micromolar level and to inhibit the growth of Trypanosma brucei brucei in cell culture at higher concentrations. From these results, significant structural features required for inhibition of this important drug target enzyme have been identified.
\end{abstract}

\section{Introduction}

Synthetic fused pyrimidines are a class of compounds with widespread biological activity on account of their relationship to naturally occurring cofactors such as folate and biopterin derivatives and to the purine bases of DNA. As such, they have found applications in antibacterial, antiparasitic, antiviral, and anticancer therapies. ${ }^{1}$ There is much concern in modern medicinal chemistry about both the evident and developing resistance of infectious organisms to existing drugs and the very limited range of compounds available for the treatment of tropical parasitic infectious diseases including malaria, trypanosomiasis, and leishmaniasis. Chemistry has responded to these challenges by developing methodologies for the synthesis of designed 'intelligent' libraries of compounds. In our work this has led to methodologies for the synthesis of diverse fused pyrimidines including pteridines, pyrido[2,3- $d]$ pyrimidines, and pyrrolo[2,3- $d]$ pyrimidines. ${ }^{2-4}$ Such templates typically contain many hydrogen bonding sites especially on the pyrimidine ring and one requirement for new biologically active compounds is a suitable balance of polarity so that there is sufficient hydrogen bonding available for binding to the target enzymes but sufficient

${ }^{a}$ WestCHEM, Department of Pure \& Applied Chemistry, University of Strathclyde, 295 Cathedral Street, Glasgow, G1 1XL, Scotland. E-mail: c.j.suckling@strath.ac.uk; Fax: +44 141548 5743; Tel: +44 1415482271 ${ }^{b}$ Strathclyde Institute for Pharmacy and Biomedical Science, University of Strathclyde 29 Taylor Street, Glasgow, G4, Scotland. E-mail: a.l.harvey@strath.ac.uk; Tel: +441415484155

'Division of Biological Chemistry and Drug Discovery, College of Life Sciences, University of Dundee, 1 Dow St, Dundee, DD2 1NT. E-mail: w.n.hunter@dundee.ac.uk; Fax: +44 1382 385764; Tel: +44 1382385745 $\dagger$ Electronic supplementary information (ESI) available: Preparation and properties of compounds listed in experimental section. CCDC reference number 705654. For ESI and crystallographic data in CIF or other electronic format see DOI: 10.1039/b818339b lipophilicity to permit passive transport into cells in the absence of active uptake.

Fused pyrimidines show an exceptional range of biological activity. Pyrido[2,3- $d$ ]pyrimidines feature in protein kinase inhibition, ${ }^{5}$ small molecule kinase inhibition, ${ }^{6}$ receptor antagonism, ${ }^{7}$ anti-infectives, ${ }^{8}$ cytotoxic ${ }^{9}$ and anti-inflammatory agents. ${ }^{10}$ Similarly broad in their applications are pyrrolo[2,3d]pyrimidines which have been investigated as inhibitors of folate metabolism and biosynthesis, ${ }^{11}$ extensively as protein kinase inhibitors, ${ }^{12}$ as antivirals, ${ }^{13}$ in combating multidrug resistance, ${ }^{14}$ in controlling gastric secretion ${ }^{15}$ and as receptor antagonists. ${ }^{16}$ Furo[2,3- $d$ ]pyrimidines have been considered as templates for drug discovery for many years with the inhibition of dihydrofolate reductase (DHFR) as the primary target. ${ }^{17}$ Similarly, 5-arylfuropyrimidines that are analogues of trimethoprim have been prepared and were found to be only weak inhibitors of DHFR. ${ }^{18}$ More recently, furopyrimidines have been found to be active as kinase inhibitors ${ }^{19}$ and as components of antiviral compounds. ${ }^{20}$ Of interest to the compounds described in this paper, arylthiopyrrolopyrimidines have featured as thymidylate synthase (TS) inhibitors. ${ }^{21}$ With the above background in mind, we have investigated the properties of series of furo[2,3$d$ ]pyrimidines and pyrrolo[2,3- $d$ ] pyrimidines containing aryl substituents attached to the heterocyclic templates. Of particular interest is the discovery of new inhibitors of pteridine reductase (PTR1), an essential enzyme for protozoan parasites of the order Kinetoplastida.

\section{Initial design of compound libraries}

In most pterin binding enzymes, there are important hydrogen bonds between the 2-amino, 3-NH, and 4-oxo groups of the pterin and the enzyme (Fig. 1). Pyrrolo[2,3- $d$ ] pyrimidines, analogous to 


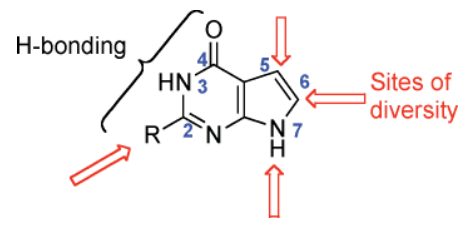

Fig. 1 Strategy for diversity.

pterins, therefore have three sites for diversification in the pyrrole ring at $\mathrm{C} 5, \mathrm{C} 6$, and $\mathrm{N} 7$ and one in the pyrimidine ring at $\mathrm{C} 2$. At $\mathrm{C} 2$, a secondary amine substituent, for example, would retain the ability to hydrogen bond but increase the lipophilicity. The use of 2-alkylthio substituents at $\mathrm{C} 2$ is a convenient approach to diversity oriented synthesis not only because of the synthetic benefit but also because relevant biological activity has been found in fused pyrimidines containing 2-alkylthio groups. ${ }^{21}$ As will be described further below, $\mathrm{C} 2$ alkylthio substituted pyrimidines have greatly reduced reactivity towards carbon electrophiles attacking at C5 compared with 2-amino compounds. This reduced reactivity has prompted the development of ring syntheses based upon Michael addition. A further challenge is that in purines themselves, displacement of C2 alkylthio groups either directly by amino nucleophiles or by oxidation and substitution of the sulfone so formed has been reported to fail. ${ }^{22,23}$

The selection of target compounds was initially based upon a high resolution molecular model of the active site of pteridine reductase 1 (PTR1) from the parasite Leishmania major complexed with several pteridines. ${ }^{24}$ In Leishmania metabolism PTR1 is able to catalyse the same reaction as DHFR and thus provides a bypass to the inhibition of the biosynthesis of tetrahydrofolate by conventional inhibitors such as methotrexate.

PTR1 is weakly inhibited by methotrexate and this contributes to the failure of antifolates as therapies against Leishmania infections. Since there are potent DHFR inhibitors already in clinical use, the discovery of a potent PTR 1 inhibitor could lead to an effective combination therapy to completely block the generation of tetrahydrofolate. The start of this project was the construction of a model of 2-amino-6-bromo-5-cyanopyrrolo[2,3d] $-4(3 H, 7 H)$-one, $\mathbf{1}$, in the active site of $L$. major PTR1 (Fig. 2). ${ }^{24}$

From this model, a number of hypotheses was derived. The model suggested that aryl substituents at C5 or C6 of a furopyrimidine or pyrrolopyrimidine could occupy one of two hydrophobic pockets at the active site (Fig. 2).A pocket near C5 was also accessible by 4-substituted-5-arylamides. In addition, substituents at $\mathrm{C} 2$ would probably be detrimental to binding to the target enzyme. By examining both diaminofuropyrimidines and deazaguanines (pyrrolopyrimidines with 2-amino-4-oxo substituents), both of the major pyrimidine substitution patterns in antifolates are covered.

\section{Synthesis}

Synthesis of furo[2,3-d]pyrimidines. 2,4-Diaminofuro[2,3$d$ ]pyrimidines are prepared readily when 2,6-diaminopyrimidin$4(3 H)$-one 2 reacts with $\alpha$-bromoketones bearing strong electron withdrawing substituents such as trifluoromethyl and ethoxycarbonyl, but not leaving groups, on the acyl carbon atom (Scheme 1). With a view to accessing diversity at several positions, ethyl 2,4-diaminofuro[2,3-d]pyrimidine-5-carboxylate 3 was prepared using ethyl bromopyruvate in $91 \%$ yield. Bromination

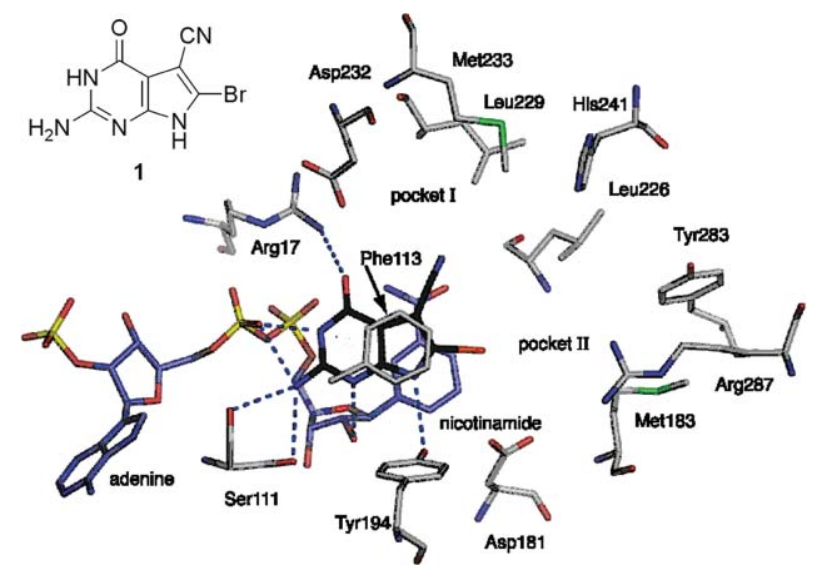

Fig. 2 A model for compound 1 in the active site of $L$. major PTR1. Atomic positions are colored according to atom type. $\mathrm{C}$ atoms of $\mathbf{1}$ are black, $\mathrm{C}$ of NADPH cyan, $\mathrm{C}$ of protein residues grey. $\mathrm{N}$ is colored blue, $\mathrm{O}$ red, $\mathrm{P}$ yellow, $\mathrm{Br}$ orange and $\mathrm{S}$ green. Blue dashed lines represent potential hydrogen bonding interactions, of distance $2.5-3.5 \AA$, formed between 1 with the cofactor and protein. Hydrogen atoms are omitted for the purpose of clarity. Inset is the chemical structure of $\mathbf{1}$.

with bromine in acetic acid afforded the 6-bromo derivative 4 (98\%), which was the primary precursor for Suzuki coupling. Hydrolysis of the ethyl ester with lithium hydroxide $(84 \%)$ afforded the 5-carboxylic acid 5 which was the precursor of the arylcarboxamides. Suzuki coupling reactions were carried out using dichlorobis(triphenylphosphine)palladium(II) in the presence of aqueous sodium carbonate as base and ethanol as organic solvent under nitrogen. ${ }^{25} \mathrm{~A}$ two phase reaction took place affording both the aryl coupled esters $\mathbf{6 a}-\mathbf{f}$ and the corresponding carboxylic acids, 7a-d and $\mathbf{f}$; the yields of esters were in the range $16-45 \%$ and the yields of carboxylic acids in the range $18-31 \%$ and the products were noticeably fluorescent. Couplings of aryl boronates with oxygen, carbon, and chlorine substituents in the aryl ring were straightforward but coupling of an aryl boronate with a 4-thiomethyl substituent was erratic and much lower yielding. In the case of 4-formylphenylboronate, the ester product 6f $(16 \%)$ was obtained from the organic phase as the diethyl acetal whereas the acidic product $7 \mathbf{e}$ was obtained as the expected 4-formyl compound. Relevant to binding to the target enzyme and as expected, the phenyl substituent and furan ring are not coplanar as the crystal structure 4-methoxyphenyl compound $\mathbf{6 c}$ shows (Fig. 3). The amides $\mathbf{8 a - f}$ were prepared using active ester coupling with benzotriazole and the products were purified by flash chromatography and aqueous base wash to remove residual benzotriazole. From these reactions altogether, 20 compounds for were obtained for evaluation.

\section{Synthesis of pyrrolo[2,3- $d]$ pyrimidines}

Palladium-mediated coupling reactions. The first investigated route to 6-arylpyrrolopyrimidines with scope for $\mathrm{C} 2$ diversification started from the 2-benzylthiopyrimdine precursor 9 (Scheme 2). Unlike C-substitution at position 5, iodination was achieved in good yield to give 10. All but one variation of the Sonogashira coupling with $\mathbf{1 0}$ or its derivatives such as the trifluoroacetamide, 11 were unsuccessful; in the successful case using the conditions of Cacchi, ${ }^{26}$ it was possible to isolate a mixture of the coupled alkynyl 


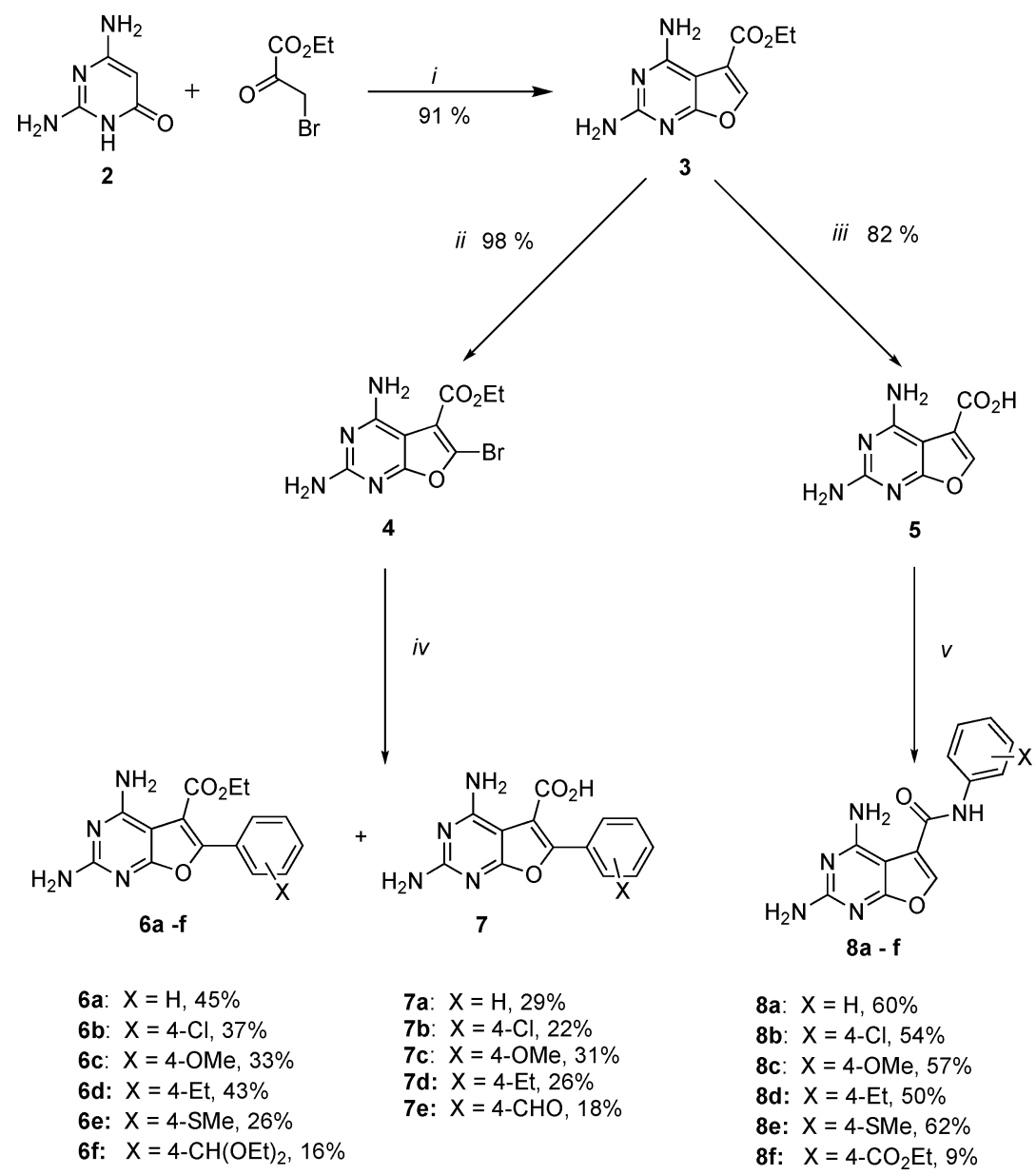

Scheme 1 Synthesis of furo[2,3-d]pyrimidines. Reagents and conditions: $i \mathrm{Et}_{3} \mathrm{~N}$, DMF, $60^{\circ} \mathrm{C}, 20 \mathrm{~h} ; i i \mathrm{Br}_{2}, \mathrm{HOAc}, 16 \mathrm{~h} ; i i i \mathrm{LiOH}$, aq. EtOH, 4 h, r.t.; iv $\left(\mathrm{PPh}_{3}\right)_{2} \mathrm{PdCl}_{2} \mathrm{ArB}(\mathrm{OH})_{2}$, aq. $\mathrm{Na}_{2} \mathrm{CO}_{3}, 60^{\circ} \mathrm{C}, 16 \mathrm{~h} ; v \mathrm{~N}$-methylmorpholine, $\mathrm{ArNH}_{2}$, HBTU, DMF, r.t., $3-18 \mathrm{~h}$.



Fig. 3 View of the structure of $\mathbf{6 c}$; ellipsoids are drawn at the $50 \%$ probability level.

pyrimidine 12 together with its cyclised product, a 6-phenylpyrrolopyrimidine, 13. Sonogashira couplings of sulfurcontaining compounds and guanine derivatives are known to be problematic ${ }^{27}$ and the presence of sulfur at $\mathrm{C} 2$ in $\mathbf{1 0}$ and 11 is likely to exacerbate these problems. Suzuki coupling of the 6-bromopyrrolopyrimidine $\mathbf{1}$, which is easily accessible from the corresponding 6-unsubstituted compound $\mathbf{1 4}$ offers an alternative entry into diversity at C6 albeit sacrificing diversity at C2 (Scheme 2). With the reacting site for coupling further removed from the potentially palladium-coordinating pyrimidine substituents, Suzuki coupling was possible in adequate yield using aryl boronates to give the products 15a-e. However if trifluoroborates were used, very good yields $(\sim 90 \%)$ were obtained and this was the method of choice. ${ }^{28}$

Michael addition by nitrosoalkenes formed in situ. With 2-alkylthiopyrimidines in related studies in the pyrido[2,3$d$ pyrimidine series ${ }^{4,29}$ we had difficulty in making the essential C5-bond using electrophilic reagents in contrast to the ready reactivity of nitrogen (diazonium, nitrosonium) and halogen (iodo, bromo) electrophiles. ${ }^{30}$ On the other hand, we had shown that the reaction of the 2-aminopyrimidine 2 with $\alpha$-bromo-oximes in the presence of tertiary bases affords pyrrolo[2,3- $d]$ pyrimidine precursors such as $\mathbf{1 7}$ typically in 50\% yield presumably via electrophilic addition to a nitrosoalkene intermediate (Scheme 3). In the case of the 2-methylthiopyrimidine, 16b, subsequent cyclisation under acidic conditions afforded the pyrrolo[2,3- $d$ ] pyrimidine ester 18 $(54 \%)$ which was hydrolysed to the carboxylic acid, $19(88 \%)$. The nitrosoalkene is an example of a soft electrophile and might be more suitable for reaction at $\mathrm{C} 5$ of a 2-alkylthiopyrimidine than a carbonyl derivative, for example. Under mildly basic conditions, it would be expected that pyrimidine-2-thiols would be reactive towards Michael acceptors. However treatment of 16a with ethyl bromopyruvate oxime in the presence of triethylamine under standard conditions gave a three component mixture of the $\mathrm{C} 5$ monosubsituted product $\mathbf{2 0}$, the $2 S$ adduct $\mathbf{2 1}$, and the bis-adduct 
<smiles>CC(C)[C@H](C)Cc1nc(SCc2ccccc2)[nH]c(=O)c1I</smiles><smiles>Nc1nc(SCc2ccccc2)[nH]c(=O)c1C#Cc1ccccc1</smiles>



Scheme 2 Palladium catalysed coupling reactions. Reagents and conditions: $i$ NIS, THF, r.t., $20 \mathrm{~h} ; i i \mathrm{Et}{ }_{3} \mathrm{~N}, \mathrm{THF}, \mathrm{TFAA}, 0^{\circ} \mathrm{C}-$ r.t., 20 h; $i i i$ phenylacetylene, $\mathrm{CuI}, \mathrm{PPh}_{3}, \mathrm{~K}_{2} \mathrm{CO}_{3}$, 1,4-dioxane, $110^{\circ} \mathrm{C}, 12 \mathrm{~h}$; iv $\mathrm{Br}_{2}$, $\mathrm{HOAc}$, r.t., $20 \mathrm{~h}$; $v$ 2-propanol/ $\mathrm{H}_{2} \mathrm{O}, \mathrm{PdCl}_{2}\left(\mathrm{PPh}_{3}\right)_{2}, \mathrm{KPhBF}_{3}$ or boronic acid, $90^{\circ} \mathrm{C}, 24 \mathrm{~h}$.

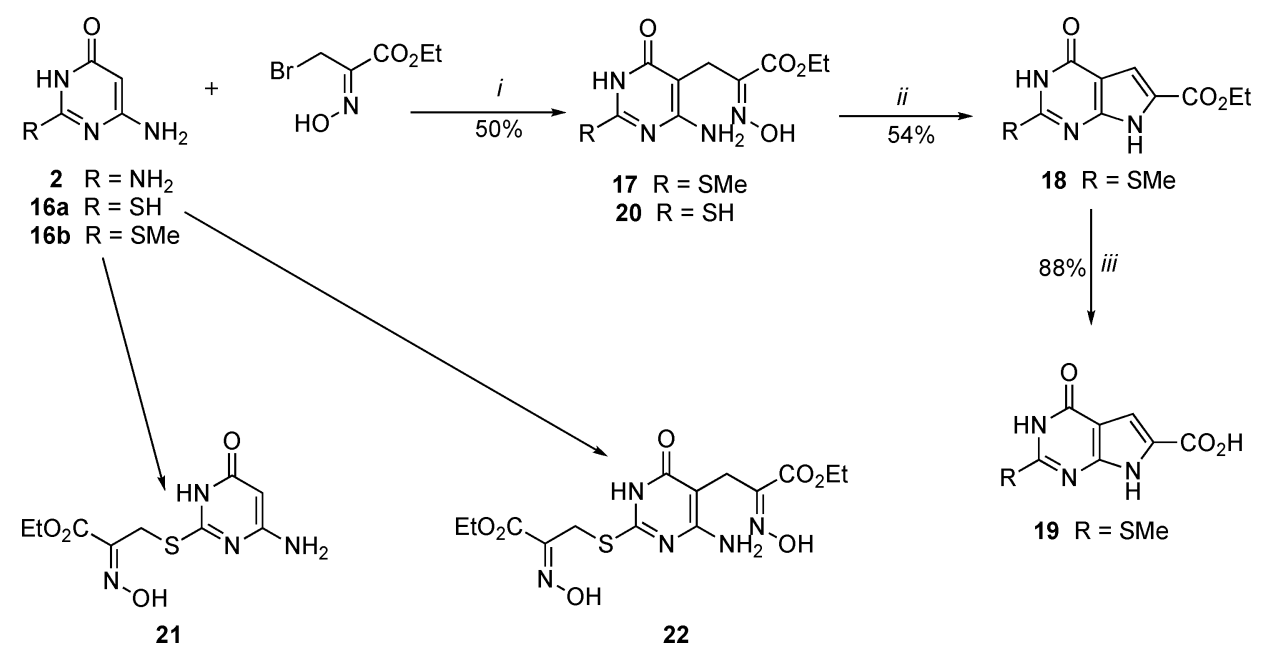

Scheme 3 Reactivity of 2-thiopyrimidine derivatives. Reagents and conditions: $i \mathrm{Et}_{3} \mathrm{~N}$, ethylbromopyruvate oxime, $\mathrm{DMF}, 0{ }^{\circ} \mathrm{C}$ to r.t., $36-48$ h; $i i$ benzaldehyde, EtOH, HCl, r.t., 3 h; iii LiOH, THF 48-96 h, then $0.1 \mathrm{M} \mathrm{HCl}$.

22 in only $25 \%$ yield. The use of the $S$-alkyl group was therefore important in our reactions. ${ }^{31}$

Michael addition of nitroalkenes. The reactivity of nitrosoalkenes together with a precedent of using maleic anhydride as the Michael acceptor ${ }^{32}$ and Taylor's synthesis of Alimta ${ }^{33}$ suggested that nitroalkenes, which are readily available, might be appropriate precursors for pyrrolo[2,3- $d]$ pyrimidine synthesis. The first example studied used nitrocyclohexene and 9 with DBU as base and surprisingly, a mixture of Michael adduct 23 (12\%) and cyclised product 24 (25\%) was formed (Scheme 4). Extension of this method to nitrostyrenes allowed Michael adducts 25 to be prepared from which 5-arylpyrrolo[2,3-d]pyrimidines 26a-d became available. The $\mathrm{C} 5$ substitution reaction was carried out using either di-isopropylethylamine or aqueous benzyltrimethylammonium hydroxide in a two phase system with ethyl acetate as cosolvent. The latter conditions afforded typically $60-90 \%$ yields. The following Nef cyclisation was examined under a variety of conditions. Using DBU as base under microwave or thermal conditions low yields (16-30\%) of the cyclised products were obtained. Better yields were obtained using titanium(III) chloride (47-71\%) and this method was adopted as standard for the Nef cyclisation in this series. 5-Substituted pyrrolo[2,3-d]pyrimidines therefore become readily available through this methodology (Scheme 4) and for studies of the diversification at C2, the same series of reactions was carried out using $\omega$-nitrostyrene and the 2-methylthiopyrimidine precursor, $\mathbf{1 6 b}$ leading to pyrrolopyrimidine $\mathbf{2 8}$.

\section{Diversification at C2 by displacement of alkylthio groups and their derivatives}

Whilst not optimised for individual cases, the reaction sequences in Schemes 3 and 4 provide access to 5- and 6-substituted 


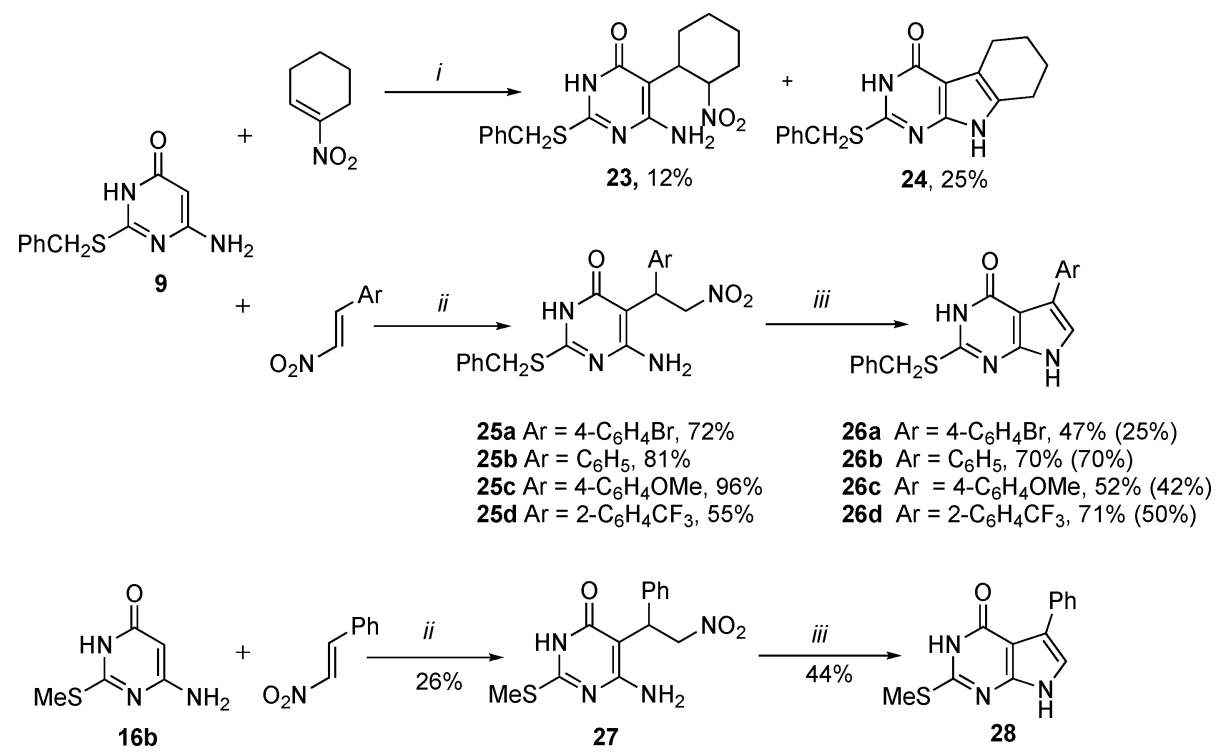

Scheme 4 Synthesis of pyrrolopyrimidines by Michael addition to nitroalkenes. Reagents and conditions: $i \mathrm{DBU}^{\mathrm{C}} \mathrm{CH}_{3} \mathrm{CN}, 80{ }^{\circ} \mathrm{C}, 4 \mathrm{~d} ; i i \mathrm{Me} \mathrm{N}^{+} \mathrm{CH}_{2} \mathrm{Ph}$ $\mathrm{OH}^{-}, 70^{\circ} \mathrm{C}, 4 \mathrm{~h}$; iii $\mathrm{TiCl}_{3}, \mathrm{NH}_{4} \mathrm{OAc}, \mathrm{NaOMe}, \mathrm{MeOH}$, r.t., $20 \mathrm{~h}$ or 3 eq $\mathrm{SnCl}_{2} .2 \mathrm{H}_{2} \mathrm{O}$, EtOAc, $85^{\circ} \mathrm{C}, 24 \mathrm{~h}$. Yields in parentheses refer to the tin(II) chloride reaction.

pyrrolo[2,3- $d]$ pyrimidines and diversification at $\mathrm{C} 2$ requires substitution of the 2-alkylthio group. This reaction has been widely used to prepare libraries of monocyclic pyrimidine derivatives especially those in which the pyrimidine bears an electron withdrawing substituent such as an ester or trifluoromethyl. ${ }^{34}$ Substitution can be directly on the alkylthio derivative itself or more typically on its oxidised derivative, the sulfone, accessible by oxidation with peracids or peroxides such as dimethyldioxirane. ${ }^{35}$ Either direct substitution or substitution after oxidation is successful in the pteridine series; essentially the pyrazine ring plays the role of an electron withdrawing substituent. In $N$-alkyl 2- or 4-oxopurines that lack an $\mathrm{NH}$ of phenolic acidity, good yields of alkylamino derivatives have been obtained by direct substitution. ${ }^{36}$ Similarly, 4 -aminopurines are reactive ${ }^{37}$ and pyrazino[3,4- $d$ ]pyrimidines undergo hydrolysis of a methylthio group at $\mathrm{C} 4$, a carbon atom activated by $\mathrm{N} 6$ in the pyrazine ring. ${ }^{38}$ However in pyrrolo[2,3-d]pyrimidines, electron withdrawing groups are absent and the pyrrole ring can be regarded as relatively electron rich. For the compounds prepared in this paper, without further derivatisation N3 is ionisable with acidity comparable to that of a phenol and the $\mathrm{p} K_{\mathrm{a}}$ decreases as a result of oxidation to the sulfone. In view of these considerations, the reactivity of 2-alkylthiopyrrolo[2,3- $d$ ]pyrimidines and their oxidised derivatives to nucleophilic substitution at $\mathrm{C} 2$ posed a challenge.

To test these possibilities, pyrrolopyrimidines were oxidised with $m$-chloroperbenzoic acid in dimethylformamide solution and the crude product subjected to substitution with benzylamine and other liquid amines that were used as solvents in order to obtain satisfactory yields (Scheme 5). With 18, which has an electron withdrawing substituent activating substitution at $\mathrm{C} 2$ of the pyrimidine by conjugation, both $\mathrm{C} 2$ substitution and amide formation was found at $100{ }^{\circ} \mathrm{C}$ for $24 \mathrm{~h}$ to give 29 and 30. Amide substitution alone was not observed but it was considered possible to find reaction conditions that would favour $\mathrm{C} 2$ substitution alone. The substitution reaction was run at several temperatures between $2{ }^{\circ} \mathrm{C}$ and $60{ }^{\circ} \mathrm{C}$ but conversions were less than $10 \%$. Even with the most extensive conversion at $60{ }^{\circ} \mathrm{C}$, the ratio of disubstitution to monosubstitution was not significantly changed. In general, cleavage of a methylthio group took place more readily than that of a benzylthio group. 5-Aryl pyrrolopyrimidines, $\mathbf{2 6}$ and $\mathbf{2 8}$, would be expected to be less reactive than 18 because they have no electron withdrawing groups that might both stabilise them to oxidation during activation of the<smiles>CCOC(=O)c1cc2c(=O)[nH]c(NCCNCC[Pb]c3ccccc3)nc2[nH]1</smiles><smiles>Cc1nc2[nH]c(C)c(-c3ccccc3)c2c(=O)[nH]1</smiles><smiles>[R]c1nc2[nH]cc(-c3ccccc3)c2c(=O)[nH]1</smiles>



Scheme 5 Substitution reactions of 2-alkylthiopyrrolo[2,3- $d$ ] pyrimidines. Reagents and conditions: $i \mathrm{~m}-\mathrm{CPBA}, \mathrm{DMF}, 0-100^{\circ} \mathrm{C}, 4-17 \mathrm{~h}$; amine nucleophile, $100{ }^{\circ} \mathrm{C}, 15 \mathrm{~h}$. 
Table 1 Biological activity of compounds prepared. na = not active. Blank cells in data columns indicate that the compound was not evaluated in the relevant test. The assays of $T$. $b$. brucei were cell based; values in roman font refer to $\mathrm{IC}_{50} \mathrm{~S}$ and values in italics refer to $\%$ inhibition at $100 \mu \mathrm{M}$



thioether and promote nucleophilic substitution. At first, it was difficult to find reaction conditions for clean oxidation of these thioethers. With many oxidising agents (oxone at $-70{ }^{\circ} \mathrm{C}$ in aqueous methanol to $80{ }^{\circ} \mathrm{C}$ in acetonitrile, dichlorodioxomolybdate with hydrogen peroxide, selenium dioxide with hydrogen peroxide, and sodium tungstate with hydrogen peroxide) the required sulfone was not obtained. However oxidation in satisfactory yield was found to be possible using $m$-chloroperbenzoic acid in DMF at room temperature. Substitution was then carried out in neat amines, benzylamine, pyrrolidine and aniline, at $100{ }^{\circ} \mathrm{C}$ for $15 \mathrm{~h}$. More volatile amines such as diethylamine and isopropylamine did not give substituted products when used in ethanol or tetrahydrofuran solution. Using neat, relatively volatile amines, C2-substituted compounds 31a-c were obtained in moderate yields $(24 \sim 55 \%)$. This result shows for the first time that the oxidation-substitution route is practical for the synthesis of libraries of pyrrolo[2,3- $d]$ pyrimidines and satisfactory in that primary alkyl, secondary alkyl, and aromatic amines were all acceptable substrates indicating that a wide diversity of products is possible.

\section{Biological evaluation}

Selected compounds were evaluated in enzyme inhibition assays against Trypanosoma brucei and Leishmania major and in a number of cell-based assays investigating antiparasitic and cytotoxicity against normal and cancer mammalian cells (Table 1). With respect to PTR1, none of the furopyrimidines proved to be significantly active. One pyrimidine precursor (9) was also found to be inactive although its close relative, 2,4-diamino6-benzylsulfanylpyridimine, was found to inhibit PTR1 from Leishmania major. Several of the pyrrolopyrimidines (15a-15d) showed significant levels of inhibition for PTR1 at best at submicromolar concentrations. The active compounds can be considered to be significant hits, especially bearing in mind their small size and potential for further structural elaboration. 
They provide a basis for structure-based design for this target. Recently, a series of quinoxaline containing compounds and some classical antifolate analogues has been described as inhibitors of pteridine reductases. ${ }^{39}$ One folate analogue was an especially potent inhibitor of PTR1 from L. major $\left(\mathrm{IC}_{50}=0.037 \mu \mathrm{M}\right)$ but in general, most compounds were active in the $10-100 \mu \mathrm{M}$ range. These data and the associated crystal structural information also contribute to the basis for design of specific PTR1 inhibitors.

Effective drugs, however, must not only bind to the target enzyme but also must be able to reach it. Our compounds were therefore evaluated in a cell based screen against Trypanosma brucei brucei. That the active compounds in the enzyme assay were inactive in the cellular assay against $T$. brucei bruce ${ }^{40}$ suggests that poor transport into the cells is a probable explanation. However two compounds, 31a and 31c in the pyrrolopyrimidine series were active in the cell based assays and these compounds notably contain benzene rings, which have a major influence on $\log$. The 2-amino-5-cyano-6-phenyl pyrrolopyrimidine 15a has a clogP of 1.08 in contrast to the 2-phenylamino-5-phenyl pyrrolopyrimidine 31c $(\operatorname{cog} \mathrm{P}=4.08)$ and the 2-benzylamino-5-phenyl pyrrolopyrimidine $31 \mathbf{a}(\operatorname{cog} \mathrm{P}=3.55)$. Some furopyrimidine esters $(\mathbf{5 a}, \mathbf{c}-\mathbf{f})$ were also hits in the cellular assay but the corresponding carboxylic acids were inactive, a further illustration of the likely importance of transport of compounds into cells. It was also notable that several of the alkylthio pyrrolopyrimidines $(\mathbf{2 6 a}, \mathbf{b}, \mathbf{d})$ were hits in the antitrypanosomal screen. However it cannot be inferred that any of the compounds active in the cellular assay exert their effect through PTR1.

In view of the universality of folate and guanine metabolism, the compounds prepared were submitted to a broad range of screens in house. ${ }^{41}$ Encouragingly, most were found to be non toxic to normal mammalian cells (L929 murine fibroblast, H92C rat heart myoblast, HS27 human foreskin fibroblast) but two pyrrolopyrimidines, 26d and 31c, showed weak but selective activity against ZR75 human epithelial breast cancer cells. As an exception, the furopyrimidine $\mathbf{6 f}$ appeared to be toxic to both normal cells and cancer cell lines.

In summary, hit compounds active against both the parasite Trypansoma brucei alone and some against the parasite Leishmania major have been identified and these compounds showed in general little mammalian cell toxicity. One exception was the pyrrolopyrimidine 31c which was active against the human breast cancer cell line ZR75. The identification of hydrophobic pockets adjacent to the pterin binding site of PTR 1 from the crystal structure has provided a useful basis for design and in the pyrrolopyrimidine series, there is a suggestion that a hydrogen bonding group as in $\mathbf{1 5 b}$ and $\mathbf{1 5 d}$ is also beneficial from the most active group of compounds, 15a-15d. Compounds in the two series described here thus appear to have potential further investigation as antiparasitic compounds.

\section{Experimental}

\section{Instrumentation and general materials}

NMR spectra were recorded on a Bruker Spectrospin spectrometer operating at $400 \mathrm{MHz}$ for ${ }^{1} \mathrm{H}$ spectra and $100 \mathrm{MHz}$ for ${ }^{13} \mathrm{C}$ spectra. Chemical shifts are reported as ppm relative to the solvent resonance. IR spectra were determined using a Mattson $1000 \mathrm{FT}$ spectrometer or a Nicolet Impact 400D FT spectrometer as a $\mathrm{KBr}$ disc. Mass spectra were measured on a JEOL JMS AX505 spectrometer at the University of Strathclyde using electrospray (ES), or chemical ionisation (CI) methods. Accurate mass recorded at the University of Glasgow on Jeol JMS-7 MStation high resolution magnetic sector using electron impact (EI) or fast atom bombardment (FAB) ionisation. Melting points, where measurable, were determined on a Reichert hot stage apparatus and are uncorrected. Microanalysis is typically unreliable in polyazabicyclic compounds due to poor combustion even in the presence of a catalyst; microanalytical data is reported where satisfactory and $400 \mathrm{MHz}$ ${ }^{1} \mathrm{H}$ NMR spectra are included in the Electronic Supplementary Information†े. TLC was carried out on silica (Merck $0.25 \mathrm{~mm}$ $60 \mathrm{~F}_{254}$ ) visualising the plates with either potassium permanganate solution or UV. Column chromatography was carried out using silica gel (230-400 mesh; 40-60 $\mu \mathrm{m}$ ) according to the method of Still et al. ${ }^{42}$ All reagents were bought from Aldrich (Gillingham, Dorset, U.K.).

\section{Furopyrimidines}

Ethyl 2,4-diaminofuro[2,3-d]pyrimidine-5-carboxylate 3. 2,4,Diaminopyrimidin-4(3H)-one 2 (3.05 g, $24.2 \mathrm{mmol})$, ethyl bromopyruvate $(1.5 \mathrm{eq}, 36.3 \mathrm{mmol}, 4.5 \mathrm{ml})$ and dry triethylamine (1.5 eq, $36.3 \mathrm{mmol}, 5 \mathrm{ml}$ ) were dissolved in anhydrous DMF $(20 \mathrm{ml})$ and stirred under nitrogen at $60{ }^{\circ} \mathrm{C}$ for $20 \mathrm{~h}$ until the reaction was complete as shown by TLC. The solvent was evaporated under reduced pressure by successive co-evaporation with toluene and ethanol. The desired furopyrimidine was obtained and recrystallised from ethanol. After being filtered, the product was dried overnight in a drying pistol. The dark-brown powder was isolated $(2.873 \mathrm{~g}, 12.9 \mathrm{mmol}, 63 \%)$. A further crop was obtained from the evaporated mother liquors by suspending the powder in a saturated aqueous sodium bicarbonate solution $(50 \mathrm{ml})$, extraction with ethyl acetate $(3 \times 70 \mathrm{ml})$. The organic layer was dried $\left(\mathrm{Na}_{2} \mathrm{SO}_{4}\right)$, filtered, and evaporated under reduced pressure to afford a total yield of $91 \%$ as a dark-brown powder; mp decomposed from 239-241 ${ }^{\circ} \mathrm{C} ; \mathrm{v}_{\max }(\mathrm{KBr}) / \mathrm{cm}^{-1} 3492$, 3367, 3307, 3176, 2975, 2938, 2738, 2677, 2491, 1697, 1614, 1574, 1556, 1474, 1374, 1373, 1170, 1113, 1075, 1037, 754; $\delta_{\mathrm{H}}\left(\left(\mathrm{CD}_{3}\right)_{2} \mathrm{SO}\right) 1.30(3 \mathrm{H}, \mathrm{t}, J=7.2), 4.32(2 \mathrm{H}, \mathrm{q}, J=7.2)$, $6.31\left(2 \mathrm{H}\right.$, br s, $\left.\mathrm{NH}_{2}\right), 7.19\left(2 \mathrm{H}\right.$, br s, $\left.\mathrm{NH}_{2}\right), 8.15(1 \mathrm{H}, \mathrm{s}) ; \delta_{\mathrm{C}}$ $\left(\left(\mathrm{CD}_{3}\right)_{2} \mathrm{SO}\right) 14.5,61.5,88.9,113.7,114.8,159.2,162.4,164.4$, 170.1; HREIMS: calcd for $\mathrm{C}_{9} \mathrm{H}_{10} \mathrm{O}_{3} \mathrm{~N}_{4}\left(\mathrm{M}^{+}\right) ; 222.0753$ found 222.0752 .

2,4-Diaminofuro[2,3- $d$ ]pyrimidine-5-carboxylic acid 5. Ethyl 2,4-diaminofuro[2,3- $d$ ]pyrimidine-5-carboxylate $3 \quad(1.00 \mathrm{~g}$, $4.5 \mathrm{mmol})$ was suspended in a mixture of water and ethanol $(5 / 1,20 \mathrm{ml})$ containing lithium hydroxide monohydrate $(3 \mathrm{eq}$, $13.5 \mathrm{mmol}, 0.326 \mathrm{~g}$ ). The mixture was stirred for $4 \mathrm{~h}$ at room temperature. The resulting solution was acidified $(\mathrm{HCl}, 1 \mathrm{M})$ to $\mathrm{pH} \mathrm{4-5.} \mathrm{The} \mathrm{product} \mathrm{was} \mathrm{separated} \mathrm{as} \mathrm{hydrated} \mathrm{crystals,} \mathrm{and} \mathrm{then}$ was dried overnight in a drying pistol to yield the desired product as a brown powder $(84 \%, 730 \mathrm{mg}, 3.76 \mathrm{mmol})$; mp decomposed above $200{ }^{\circ} \mathrm{C}$ (decomp.); $v_{\max }(\mathrm{KBr}) / \mathrm{cm}^{-1} 3356,3161,1709,1589$, 1558, 1433, 1388, 1315, 2242, 1166, 1130, 1113, 1074, 1050, 1004, $810,756,702,696,671,593 ; \delta_{\mathrm{H}}\left(\left(\mathrm{CD}_{3}\right)_{2} \mathrm{SO}\right) 6.25\left(2 \mathrm{H}, \mathrm{br} \mathrm{s}, \mathrm{NH}_{2}\right)$, $7.16\left(2 \mathrm{H}\right.$, br d, $\left.\mathrm{NH}_{2}\right), 8.05(1 \mathrm{H}, \mathrm{s}), 12.54(1 \mathrm{H}$, br s $) ; \delta_{\mathrm{C}}\left(\left(\mathrm{CD}_{3}\right)_{2} \mathrm{SO}\right)$ 
89.0, 114.5, 144.1, 159.0, 162.0, 165.7, 169.7; HRFABMS: calcd for $\mathrm{C}_{7} \mathrm{H}_{6} \mathrm{O}_{3} \mathrm{~N}_{4}\left(\mathrm{M}+\mathrm{H}^{+}\right)$; 194.0440 found 195.0513.

Ethyl 2,4-diamino-6-bromofuro[2,3- $d$ ]pyrimidine-5-carboxylate 4. Ethyl 2,4-diaminofuro[2,3- $d$ ]pyrimidine-5-carboxylate $\mathbf{3}$ $(2.00 \mathrm{~g}, 9.00 \mathrm{mmol})$ was suspended in glacial acetic acid $(30 \mathrm{ml})$. Bromine ( $2 \mathrm{eq}, 17.98 \mathrm{mmol}, 920 \mu \mathrm{l}$ ) was added to give an orange solution. The solution was stirred at room temperature for $16 \mathrm{~h}$. A yellow product precipitated and was filtered off, washed with acetic acid and dried overnight to afford the title compound (2.651 mg, $8.81 \mathrm{mmol}, 98 \%$ ); $\mathrm{mp}$ which decomposed above $190{ }^{\circ} \mathrm{C} ; v_{\max }(\mathrm{KBr}) / \mathrm{cm}^{-1} 3394,3305,3140,2999,2936,1723,1694$, 1678, 1657, 1609, 1537, 1472, 1422, 1360, 1263, 1169, 1120, 1077, $1004,759,649,594,558 ; \delta_{\mathrm{H}}\left(\left(\mathrm{CD}_{3}\right)_{2} \mathrm{SO}\right) 1.33(3 \mathrm{H}, \mathrm{t}, J=7.1)$, $4.38(2 \mathrm{H}, \mathrm{q}, J=7.1), 7.98\left(2 \mathrm{H}\right.$, br s, $\left.\mathrm{NH}_{2}\right), 8.38\left(2 \mathrm{H}\right.$, br s, $\left.\mathrm{NH}_{2}\right)$; $\delta_{\mathrm{C}}\left(\left(\mathrm{CD}_{3}\right)_{2} \mathrm{SO}\right) 13.8,62.3,90.7,113.1,129.8,152.6,154.3,162.4$; HR-FABMS: calcd for $\mathrm{C}_{9} \mathrm{H}_{9} \mathrm{O}_{3} \mathrm{~N}_{4}{ }^{79} \mathrm{Br}\left(\mathrm{M}+\mathrm{H}^{+}\right) ; 299.9858$ found 300.9944; calcd for $\mathrm{C}_{9} \mathrm{H}_{9} \mathrm{O}_{3} \mathrm{~N}_{4}{ }^{81} \mathrm{Br}\left(\mathrm{M}+\mathrm{H}^{+}\right)$; 301.9838 found 302.9924 .

\section{General procedure $A$ for the coupling reaction between 4 and corresponding boronic acid}

Ethyl 2,4-diamino-6-bromofuro[2,3- $d$ ] pyrimidine-5-carboxylate 4 $(0.5 \mathrm{~g}, 1.66 \mathrm{mmol})$ was suspended in ethanol $(15 \mathrm{ml})$. The corresponding phenylboronic acid (1.4 eq) was added and the solution was degassed with $\mathrm{N}_{2}$ for 5 minutes. Then, $\mathrm{PdCl}_{2}\left(\mathrm{PPh}_{3}\right)_{2}$ ( $5 \mathrm{~mol} \%, 0.084 \mathrm{mmol}, 58 \mathrm{mg}$ ) was added, and the solution was degassed. An aqueous $\mathrm{Na}_{2} \mathrm{CO}_{3}$ solution $(2 \mathrm{M}, 15 \mathrm{ml}$ ) was added, and the solution was degassed further. The reaction was heated at $60{ }^{\circ} \mathrm{C}$ for an average of 16 hours or until completion of the reaction as shown by TLC. The reaction mixture was then cooled to room temperature and extracted with ethyl acetate $(3 \times 100 \mathrm{ml})$. The organic layer was washed successively with brine $(30 \mathrm{ml})$, water $(30 \mathrm{ml})$, and dried $\left(\mathrm{Na}_{2} \mathrm{SO}_{4}\right)$, filtered and concentrated under reduced pressure. The resulting powder was dissolved in methanol, adsorbed on to silica, and purified by flash chromatography using ethyl acetate/hexane (from 40/60 to $100 / 0)$. In some cases, a further recrystallisation was required: the compound was dissolved in a minimum of ethyl acetate and recrystallised with the addition of hexane.

Ethyl 2,4-diamino-6-phenylfuro[2,3- $d$ ]pyrimidine-5-carboxylate 6a. Obtained using the general coupling procedure with phenylboronic acid (2 eq, $3.32 \mathrm{mmol}, 405 \mathrm{mg}$ ) for $16 \mathrm{~h}$ as an off-white fluorescent powder was isolated (223 mg, $0.75 \mathrm{mmol}, 45 \%)$; mp 174-177 ${ }^{\circ} \mathrm{C}$. Found: $\mathrm{C}, 60.8 ; \mathrm{H}, 5.0 ; \mathrm{N}, 18.7 ; \mathrm{C}_{15} \mathrm{H}_{14} \mathrm{O}_{3} \mathrm{~N}_{4}$ requires C, 60.4; H, 4.7; N, 18.8\%. $v_{\max }(\mathrm{KBr}) / \mathrm{cm}^{-1} 3503,3462,3380,3169$, 1688, 1647, 1618, 1567, 1460, 1374, 1270, 1240, 1140, 1093, 1066, $779,764,696 ; \delta_{\mathrm{H}}\left(\left(\mathrm{CD}_{3}\right)_{2} \mathrm{SO}\right) 1.12(3 \mathrm{H}, \mathrm{t}, J=7.1), 4.23(2 \mathrm{H}, \mathrm{q}, J=$ 7.1), $6.32\left(2 \mathrm{H}\right.$, br s, $\left.\mathrm{NH}_{2}\right), 7.25\left(2 \mathrm{H}\right.$, br s, $\left.\mathrm{NH}_{2}\right), 7.47(3 \mathrm{H}, \mathrm{m}), 7.72$ $(2 \mathrm{H}, \mathrm{dd}, J=7.6,4.4) ; \delta_{\mathrm{C}}\left(\left(\mathrm{CD}_{3}\right)_{2} \mathrm{SO}\right) 13.5,61.3,90.7,108.2,127.8$, 128.0, 129.4, 129.7, 152.5, 158.8, 161.7, 164.4, 168.0; HRFABMS: calcd for $\mathrm{C}_{15} \mathrm{H}_{14} \mathrm{O}_{3} \mathrm{~N}_{4}\left(\mathrm{M}+\mathrm{H}^{+}\right) ; 298.1066$ found 299.1142.

Similarly prepared were ethyl 2,4-diamino-6-(4-chlorophenyl)furo[2,3- $d$ ]pyrimidine-5-carboxylate $\mathbf{6 b}$, ethyl 2,4-diamino-6-(4methoxyphenyl)furo[2,3-d]pyrimidine-5-carboxylate $\mathbf{6 c}$, ethyl 2, 4-diamino-6-(4-ethylphenyl)furo[2,3- $d]$ pyrimidine-5-carboxylate 6d, ethyl 2,4-diamino-6-(4-(methylthio)phenyl)furo[2,3-d]pyrimidine-5-carboxylate 6e, ethyl 2,4-diamino-6-(4-(diethoxymethyl)- phenyl)furo[2,3- $d]$ pyrimidine-5-carboxylate 6f, details of which can be found in the Supplementary Information.

\section{General procedure B for the isolation of carboxylic acids from Suzuki coupling reactions}

The aqueous layer from the extraction of the Suzuki coupling reaction was filtered. Then, under stirring, the solution was acidified to $\mathrm{pH} 4$ by the means of a dilute $\mathrm{HCl}(1 \mathrm{M})$. The product was separated as hydrated crystals, and then was dried overnight.

2,4-Diamino-6-phenylfuro[2,3- $d$ ]pyrimidine-5-carboxylic acid 7a. Obtained using the general acidification procedure on the synthesis of $\mathbf{6 a}$ as a grey fluorescent powder $(106 \mathrm{mg}, 0.48 \mathrm{mmol}$, $29 \%$ ); mp which decomposed above $275{ }^{\circ} \mathrm{C} ; v_{\max }(\mathrm{KBr}) / \mathrm{cm}^{-1}$ 3449, 3311, 3161, 2846, 2672, 1673, 1597, 1550, 1490, 1424, $1390,1303,1182,1052,1010,807,763,694,604,559,542 ; \delta_{\mathrm{H}}$ $\left(\left(\mathrm{CD}_{3}\right)_{2} \mathrm{SO}\right) 6.35\left(2 \mathrm{H}\right.$, br s, $\left.\mathrm{NH}_{2}\right), 7.47(3 \mathrm{H}, \mathrm{m}), 7.60(2 \mathrm{H}$, br s, $\left.\mathrm{NH}_{2}\right), 7.73(2 \mathrm{H}, \mathrm{d}, J=7.7) ; \delta_{\mathrm{C}}\left(\left(\mathrm{CD}_{3}\right)_{2} \mathrm{SO}\right) 91.0,109.0,127.9$, 129.4, 129.5, 129.5, 152.4, 158.5, 161.2, 165.9; HRFABMS: calcd for $\mathrm{C}_{13} \mathrm{H}_{10} \mathrm{O}_{3} \mathrm{~N}_{4}\left(\mathrm{M}+\mathrm{H}^{+}\right) ; 270.0753$ found 271.0835 .

Similarly prepared were: 2,4-diamino-6-(4-chlorophenyl)furo[2,3-d]pyrimidine-5-carboxylic acid 7b, 2,4-diamino-6-(4-methoxyphenyl)furo[2,3- $d$ ]pyrimidine-5-carboxylic acid 7c, 2,4-diamino6-(4-ethylphenyl)furo[2,3- $d$ ]pyrimidine-5-carboxylic acid 7d, and 2,4-diamino-6-(4-formylphenyl)furo[2,3- $d$ ]pyrimidine-5-carboxylic acid 7e, details of which can be found in the Supplementary Information.

\section{General procedure $\mathbf{C}$ for the synthesis of amides}

2,4-Diaminofuro[2,3- $d$ ]pyrimidine-5-carboxylic acid 5 (200 mg, $1.04 \mathrm{mmol}$ ) was dissolved in anhydrous DMF (4 ml) under nitrogen with warming. After being cooled, NMM (1.2 eq, $1.27 \mathrm{mmol}$, $140 \mu \mathrm{l})$ was added, followed by HBTU (2 eq, $2.08 \mathrm{mmol}, 260 \mu \mathrm{l})$. Once it was dissolved, the aromatic amine (2 eq, $2.08 \mathrm{mmol}$ ) dissolved in DMF $(200 \mu \mathrm{l})$ was added. The reaction was stirred at room temperature under nitrogen for between 3 and $18 \mathrm{~h}$. DMF was removed under reduced pressure to afford a powder that was dissolved in ethyl acetate $(80 \mathrm{ml})$. The organic layer was washed water $(15 \mathrm{ml})$, and the resulting aqueous layer was extracted with ethyl acetate $(2 \times 80 \mathrm{ml})$. All the organic layers were combined and washed with brine $(20 \mathrm{ml})$, and water $(20 \mathrm{ml})$, and finally dried $\left(\mathrm{Na}_{2} \mathrm{SO}_{4}\right)$ and concentrated under reduced pressure. The resulting powder was dissolved in methanol, adsorbed on to silica, and purified by silica gel chromatography using ethyl acetate/hexane (from $80 / 20$ to $100 / 0$ ). The purified powder was triturated with aqueous sodium hydroxide solution $(1 \mathrm{M})$, and then filtered to give the desired compound.

2,4-Diamino- $N$-phenylfuro[2,3- $d$ ]pyrimidine-5-carboxamide 8 a. Obtained using the general synthesis procedure with aniline ( 2 eq, $2.08 \mathrm{mmol}, 190 \mu \mathrm{l})$ as a yellow-brown powder ( $168 \mathrm{mg}, 0.62 \mathrm{mmol}$, $68 \%$ ); mp that sublimed at $212{ }^{\circ} \mathrm{C}$ and melted at $266-268{ }^{\circ} \mathrm{C}$. $v_{\max }$ $(\mathrm{KBr}) / \mathrm{cm}^{-1} 3473,3293,3135,1662,1619,1595,1548,1535,1495$, 1464, 1442, 1387, 1315, 1264, 1240, 1116, 1098, 1041, 876, 800, 755,$693 ; \delta_{\mathrm{H}}\left(\left(\mathrm{CD}_{3}\right)_{2} \mathrm{SO}\right) 6.22\left(2 \mathrm{H}\right.$, br s, $\left.\mathrm{NH}_{2}\right), 7.13(1 \mathrm{H}, J=7.3)$, $7.37(2 \mathrm{H}, \mathrm{m}), 7.44\left(2 \mathrm{H}\right.$, br s, $\left.\mathrm{NH}_{2}\right), 7.67(2 \mathrm{H}, \mathrm{d}, J=7.5), 8.32(1 \mathrm{H}$, s), $10.21(1 \mathrm{H}$, br s, $\mathrm{NH}) ; \delta_{\mathrm{C}}\left(\left(\mathrm{CD}_{3}\right)_{2} \mathrm{SO}\right) 89.3,117.3,120.8,124.1$, 
128.7, 138.2, 140.4, 159.1, 161.7, 161.9, 161.4; HR-FABMS: calcd for $\mathrm{C}_{13} \mathrm{H}_{11} \mathrm{O}_{2} \mathrm{~N}_{5}\left(\mathrm{M}+\mathrm{H}^{+}\right) ; 269.0913$ found 270.0990 .

Similarly prepared were: 2 ,4-diamino- $N$-(4-chlorophenyl)furo[2,3- $d$ ] pyrimidine-5-carboxamide $\mathbf{8 b}, 2,4$-diamino- $N$-(4-methoxyphenyl)furo[2,3- $d$ ]pyrimidine-5-carboxamide 8c, 2,4-diamino$N$-(4-ethylphenyl)furo[2,3- $d$ ] pyrimidine-5-carboxamide $8 d, 2,4-$ diamino- $N$-(4-(methylthio)phenyl)furo[2,3- $d$ ] pyrimidine-5-carboxamide 8e, and ethyl 4-(2,4-diaminofuro[2,3- $d$ ] pyrimidine-5-carboxamido)benzoate $\mathbf{8 f}$, details of which can be found in the Supplementary Information.

\section{Pyrrolopyrimidines}

6-Amino-2-(benzylthio)-5-iodopyrimidin-4(3H)-one 10 . To a $50 \mathrm{ml}$ round bottom flask, protected from light by aluminium foil, was added 6-amino-2-(benzylthio)pyrimidin-4(3H)-one 9 ( $0.8 \mathrm{~g}$, $3.4 \mathrm{mmol})$ in THF ( $10 \mathrm{ml}$, anhydrous). $N$-Iodosuccinimide $(0.8 \mathrm{~g}$, $3.6 \mathrm{mmol}, 1.1 \mathrm{eq})$ dissolved in THF (10 ml, anhydrous) was added. The reaction mixture was stirred under nitrogen, at room temperature for $20 \mathrm{~h}$ in the dark. The solvents were removed under reduced pressure and the residue was dissolved in DCM $(50 \mathrm{ml})$. The reaction mixture was washed with water, dried $\left(\mathrm{MgSO}_{4}\right)$ and concentrated under reduced pressure to give $\mathbf{1 0}$ as a brown solid (2.56 g, $7.1 \mathrm{mmol}, 82 \%) ; \mathrm{mp} 204-206^{\circ} \mathrm{C} ; v_{\max }(\mathrm{KBr}) / \mathrm{cm}^{-1} 3468$, $3357,1617,1590,1562,1524,1444,1411,1271,1222,1050,988$, $951,876,758,698,543,509 ; \delta_{\mathrm{H}}\left(\left(\mathrm{CD}_{3}\right)_{2} \mathrm{SO}\right) 4.36\left(2 \mathrm{H}, \mathrm{s}, \mathrm{CH}_{2}\right), 6.75$ $\left(2 \mathrm{H}, \mathrm{Br} \mathrm{s}, \mathrm{NH}_{2}\right), 7.22-7.25(1 \mathrm{H}, \mathrm{m}), 7.30-7.33(2 \mathrm{H}, \mathrm{m}), 7.46-7.44$ $(2 \mathrm{H}, \mathrm{m}) ; \delta_{\mathrm{C}}\left(\left(\mathrm{CD}_{3}\right)_{2} \mathrm{SO}\right) 34.4,53.2,128.6,129.4,130.6,138.6,154.0$, 163.1, 178.5; HREIMS: calcd for $\mathrm{C}_{11} \mathrm{H}_{10} \mathrm{IN}_{3} \mathrm{OS}\left(\mathrm{M}^{+}\right)$; 359.9668 found 359.9661 .

$N$-(2-(Benzylthio)-1,6-dihydro-5-iodo-6-oxopyrimidin-4-yl)2,2,2-trifluoroacetamide 11. To a solution of 6-amino-2(benzylthio)-5-iodopyrimidin-4(3H)-one $9(0.99 \mathrm{~g}, 2.7 \mathrm{mmol})$ and triethylamine $(380 \mu \mathrm{l}, 5.4 \mathrm{mmol}, 2 \mathrm{eq})$ in THF $(10 \mathrm{ml})$, trifluoroacetic anhydride $(1.1 \mathrm{ml}, 7.8 \mathrm{mmol}, 3 \mathrm{eq})$ was added at $0^{\circ} \mathrm{C}$ dropwise. The solution was stirred at room temperature for $20 \mathrm{~h}$. Then, the reaction mixture was diluted with ethyl acetate $(30 \mathrm{ml})$, washed with a saturated sodium hydrogen carbonate solution and dried $\left(\mathrm{MgSO}_{4}\right)$ and concentrated under reduced pressure to give the title compound 11 as a yellow solid $(0.84 \mathrm{~g}, 1.8 \mathrm{mmol}, 85 \%)$; $\mathrm{mp} 93-95^{\circ} \mathrm{C} ; v_{\max }(\mathrm{KBr}) / \mathrm{cm}^{-1} 3461,3362,3028,1735,1658,1607$, $1567,1528,1495,1452,1321,1202,1161,1002,907,758,699 ; \delta_{\mathrm{H}}$ $\left(\left(\mathrm{CD}_{3}\right)_{2} \mathrm{SO}\right) 2.56\left(1 \mathrm{H}, \mathrm{s}, \mathrm{NHCOCF}_{3}\right), 4.42\left(2 \mathrm{H}, \mathrm{s}, \mathrm{CH}_{2}\right), 7.22-7.34$ (3H, m, Ph, CH, CH), 7.40-7.46 (2H, m, Ph, CH), 12.39 (1H, br s, $\mathrm{NH}) ; \delta_{\mathrm{C}}\left(\left(\mathrm{CD}_{3}\right)_{2} \mathrm{SO}\right) 34.2,60.1,127.6,128.8,129.5,137.8,151.8$, 161.3, 165.8, 171.2; LRMS: $\left(\mathrm{M}^{+}-1\right)$ found 453.93; $\mathrm{C}_{13} \mathrm{H}_{9} \mathrm{~F}_{3} \mathrm{IN}_{3} \mathrm{O}_{2} \mathrm{~S}$ requires 454.94 .

6-Amino-2-(benzylthio)-5-(2-phenylethynyl)pyrimidin-4(3H)one 12 and 2-(benzylthio)-6-phenyl-3 $H$-pyrrolo[2,3- $d$ |pyrimidin4(7H)-one 13. To a solution of $N$-(2-(benzylthio)-5-iodo-1,6dihydro-6-oxopyrimidin-4-yl)-2,2,2-trifluoroacetamide 10 (0.18 g, $0.43 \mathrm{mmol})$ in 1,4-dioxane $(10 \mathrm{ml})$, phenylacetylene $(52 \mu \mathrm{l}$, $0.47 \mathrm{mmol}, 1.1 \mathrm{eq})$, copper iodide $(0.016 \mathrm{~g}, 0.08 \mathrm{mmol}, 0.2 \mathrm{eq})$, triphenylphosphine $(0.04 \mathrm{~g}, 0.15 \mathrm{mmol}, 0.35 \mathrm{eq})$, and potassium carbonate $(0.12 \mathrm{~g}, 0.85 \mathrm{mmol}, 2 \mathrm{eq})$ were added. The solution was stirred at $110^{\circ} \mathrm{C}$ for $12 \mathrm{~h}$. Once cooled, the reaction mixture was concentrated under reduced pressure. Purification of crude products was achieved by column chromatography using ethyl acetate/hexane (1:1) as eluant. The pyrimidine $\mathbf{1 2}$ was obtained as an orange solid (36\%) and the pyrrolopyrimidine $\mathbf{1 3}$ as an orange solid $(21 \%)$.

Characterisation of 12; mp $93-96{ }^{\circ} \mathrm{C}$; $v_{\max }(\mathrm{KBr}) / \mathrm{cm}^{-1} 3458$, $2923,1678,1612,1568,1543,1494,1463,1297,1210,1141,1121$, $1070,997,957,802,723,694,542 ; \delta_{\mathrm{H}}\left(\left(\mathrm{CD}_{3}\right)_{2} \mathrm{SO}\right) 4.38(2 \mathrm{H}, \mathrm{s})$, $6.73\left(2 \mathrm{H}\right.$, br s, $\left.\mathrm{NH}_{2}\right), 7.21-7.31(4 \mathrm{H}, \mathrm{m}), 7.42-7.44(2 \mathrm{H}, \mathrm{m})$, 7.52-7.73 $(4 \mathrm{H}, \mathrm{m}), 12.35(1 \mathrm{H}, \mathrm{br} \mathrm{s}, \mathrm{NH}) ; \delta_{\mathrm{C}}\left(\left(\mathrm{CD}_{3}\right)_{2} \mathrm{SO}\right) 34.2$, $112.9,116.0,122.3,127.4,128.8,128.9,129.3,129.4,133.6,138.0$, 159.6, 159.7, 172.9; Characterisation of $13 ; \mathrm{mp}>230{ }^{\circ} \mathrm{C}$; $v_{\max }$ $(\mathrm{KBr}) / \mathrm{cm}^{-1} 3459,1686,1635,1553,1458,1295,1208,1140,999$, $961,842,804,779,724,694 ; \delta_{\mathrm{H}}\left(\left(\mathrm{CD}_{3}\right)_{2} \mathrm{SO}\right) 4.31\left(2 \mathrm{H}, \mathrm{s}, \mathrm{CH}_{2}\right)$, $5.61\left(1 \mathrm{H}\right.$, br s, NH), 7.19-7.38 $(7 \mathrm{H}, \mathrm{m}), 7.34-7.54(3 \mathrm{H}, \mathrm{m}) ; \delta_{\mathrm{C}}$ $\left(\left(\mathrm{CD}_{3}\right)_{2} \mathrm{SO}\right) 34.3,86.2,116.0,125.0,128.1,128.4,129.1,131.6$, $132.5,139.5,159.7,162.5,167.4$.

2-Amino-6-bromo-4,7-dihydro-4-oxo-3 $H$-pyrrolo[2,3- $d$ ]pyrimidine-5-carbonitrile 1. To a suspension of 2-amino-4,7-dihydro4-oxo-3H-pyrrolo[2,3- $d$ ] pyrimidine-5-carbonitrile $\mathbf{1 3}^{\mathbf{4 3}}(1.09 \mathrm{~g}$, $6.24 \mathrm{mmol})$ in glacial acetic acid $(70 \mathrm{ml})$ was added bromine $(480 \mu \mathrm{l}, 9.40 \mathrm{mmol}, 1.5 \mathrm{eq})$. The mixture was stirred at room temperature for $20 \mathrm{~h}$ then heated to $60{ }^{\circ} \mathrm{C}$ for $24 \mathrm{~h}$ prior to the solvent being concentrated under reduced pressure. The solid product was dried in a vacuum desiccator for $12 \mathrm{~h}$ to yield $\mathbf{1}$ as a light brown solid $(1.48 \mathrm{~g}, 5.83 \mathrm{mmol}, 94 \%) ; \mathrm{mp}>300{ }^{\circ} \mathrm{C}$; $v_{\max }$ $(\mathrm{KBr}) / \mathrm{cm}^{-1} 3392,3296,3101,2785,2235,1691,1570,1519,1448$, $1415,1383,1284,1219,1135,796 ; \delta_{\mathrm{H}}\left(\left(\mathrm{CD}_{3}\right)_{2} \mathrm{SO}\right) 6.71(2 \mathrm{H}, \mathrm{br} \mathrm{s}$ $\left.\mathrm{NH}_{2}\right), 10.54(1 \mathrm{H}$, br s NH$), 10.83(1 \mathrm{H}$, br s, $\mathrm{NH}) ; \delta_{\mathrm{C}}\left(\left(\mathrm{CD}_{3}\right)_{2} \mathrm{SO}\right)$ 88.4, 100.0, 110.9, 114.6, 151.6, 153.9, 156.3; HREIMS: calcd for $\mathrm{C}_{7} \mathrm{H}_{4} \mathrm{BrN}_{5} \mathrm{O}\left(\mathrm{M}^{+}\right) ; 253.9677 / 255.9657$ found 253.9683/255.9661.

2-Amino-4,7-dihydro-4-oxo-6-phenyl-3H-pyrrolo[2,3d]pyrimidine-5-carbonitrile 15a.

(a) Using phenyl boronic acid. 2-Amino-6-bromo-4,7-dihydro4-oxo-3H-pyrrolo[2,3- $d$ ]pyrimidine-5-carbonitrile $\mathbf{1 4}(0.16 \mathrm{~g}$, $0.63 \mathrm{mmol})$, phenylboronic acid $(0.16 \mathrm{~g}, 1.31 \mathrm{mmol}, 2.1 \mathrm{eq})$ and $\mathrm{PdCl}_{2}\left(\mathrm{PPh}_{3}\right)_{2}(0.023 \mathrm{~g}, 0.03 \mathrm{mmol}, 5 \mathrm{~mol} \%)$ were suspended in $10 \% \mathrm{NH}_{4} \mathrm{OH}(20 \mathrm{ml})$. The suspension was de-oxygenated using nitrogen. Under an atmosphere of nitrogen, an aqueous solution of sodium carbonate ( $2 \mathrm{M}$ in water, $20 \mathrm{ml}$ ) was added and the mixture was again de-oxygenated for $10 \mathrm{~min}$. The reaction mixture was stirred at $70{ }^{\circ} \mathrm{C}$ for $24 \mathrm{~h}$ under nitrogen. The reaction mixture, once cooled to room temperature, was concentrated under reduced pressure. Ethyl acetate was added to the solid and then solution was then washed with water and brine. The organic layers were collected $\left(\mathrm{MgSO}_{4}\right)$, filtered and evaporated under reduced pressure. The solid material was then purified by column chromatography using hexane/ethyl acetate (2:1) as eluant, increasing the polarity up to $1: 1$ methanol/ethyl acetate. The desired product 15a was obtained as a light brown solid $(0.017 \mathrm{~g}, 0.07 \mathrm{mmol}, 11 \%) ; \mathrm{mp}>230^{\circ} \mathrm{C} ; \mathrm{v}_{\max }(\mathrm{KBr}) / \mathrm{cm}^{-1} 3077$, 3042, 1964, 1603, 1494, 1442, 1367, 1348, 1306, 1179, 1086, 1024, $759,700,578 ; \delta_{\mathrm{H}}\left(\left(\mathrm{CD}_{3}\right)_{2} \mathrm{SO}\right) 6.50\left(2 \mathrm{H}, \mathrm{br} \mathrm{s}, \mathrm{NH}_{2}\right), 7.43(1 \mathrm{H}, \mathrm{t}, J=$ 7.6), $7.54(2 \mathrm{H}, \mathrm{dd}, J=8.2,7.6), 7.84(2 \mathrm{H}, \mathrm{d}, J=8.2), 10.74(1 \mathrm{H}$, br s, NH), $12.39\left(1 \mathrm{H}\right.$, br s, NH); $\delta_{\mathrm{C}}\left(\left(\mathrm{CD}_{3}\right)_{2} \mathrm{SO}\right) 82.3,99.3,100.2$, 116.2, 126.2, 128.9, 129.3, 138.4, 152.2, 154.0, 157.3; HREIMS: calcd for $\mathrm{C}_{13} \mathrm{H}_{9} \mathrm{~N}_{5} \mathrm{O}\left(\mathrm{M}^{+}\right) ; 252.0885$ found 252.0880.

(b) Using potassium trifluoro(phenyl) borate. 2-Propanol (5 ml) was mixed with water $(2.5 \mathrm{ml})$ under nitrogen. Into this stirred 
solution were added compound $\mathbf{1 4}(0.1 \mathrm{~g}, 0.39 \mathrm{mmol})$ and $\mathrm{PdCl}_{2}\left(\mathrm{PPh}_{3}\right)_{2}(14 \mathrm{mg}, 0.02 \mathrm{mmol})$. After $5 \mathrm{~min}$, potassium trifluoro(phenyl)borate $(86 \mathrm{mg}, 0.47 \mathrm{mmol})$ and $t$-butylamine (86 $\mathrm{mg}, 1.17 \mathrm{mmol})$ were added. The resulting mixture was stirred in an oil bath at $85{ }^{\circ} \mathrm{C}$ for $4 \mathrm{~d}$, methanol $(20 \mathrm{ml})$ was added, and concentrated. The residue was purified by column chromatography (silica gel/methanol:ethyl acetate $=1: 1$ ) to give the product 15a as a yellow solid (0.9 g, $0.36 \mathrm{mmol}, 92 \%)$; Analytical data were identical to those reported above.

Similarly prepared were: 2-amino-4,7-dihydro-6-(4-methoxyphenyl)-4-oxo-3H-pyrrolo[2,3- $d$ ]pyrimidine-5-carbonitrile $\mathbf{1 5 b}$, 2-amino-6-(4-ethylphenyl)-4,7-dihydro-4-oxo-3 $H$-pyrrolo[2,3- $d$ ]pyrimidine-5-carbonitrile 15c, and 2-amino-4,7-dihydro-6-(3,4methylenedioxyphenyl)-4-oxo- $3 H$-pyrrolo[2,3- $d]$ pyrimidine-5carbonitrile 15d, 2-amino-6-(3-formyl)-4,7-dihydro-4-oxo-3 $\mathrm{H}$ pyrrolo[2,3- $d$ ]pyrimidine-5-carbonitrile 15e details of which can be found in the Supplementary Information.

3-(4-Amino-2-methylsulfanyl-6-oxo-1,6-dihydropyrimidin-5-yl)2-hydroxyiminopropionic acid ethyl ester 17.

(a) Thermal method. 6-Amino-2-methylsulfanyl-3 $\mathrm{H}$-pyrimidin-4-one 16b (1.02 g, $6.5 \mathrm{mmol})$ was dissolved in dry DMF $(15 \mathrm{ml})$. Triethylamine $(0.65 \mathrm{~g}, 6.5 \mathrm{mmol})$ was added and the mixture was stirred under nitrogen at room temperature for $1 \mathrm{~h}$. A solution of ethyl bromopyruvate oxime $(1.51 \mathrm{~g}, 7.2 \mathrm{mmol})$ in dry DMF $(15 \mathrm{ml})$ was added over a period of $4 \mathrm{~h}$. Stirring was continued for a further $2 \mathrm{~d}$. The solution was evaporated under reduced pressure and the residue was dissolved in a solution of ethyl acetate and methanol $(4: 1,10 \mathrm{ml})$. The resulting solution was absorbed onto a silica gel chromatography column and eluted with $100 \%$ ethyl acetate, increasing the polarity up to $4: 1$ ethyl acetate/methanol solution. The desired product was crystallised from ethyl acetate and hexane, and dried at $0.1 \mathrm{~mm} \mathrm{Hg} / 40{ }^{\circ} \mathrm{C}$ to give a pale yellow solid $(0.43 \mathrm{~g}, 1.5 \mathrm{mmol}, 21 \%)$; mp $123-148{ }^{\circ} \mathrm{C}$ (slow decomposition); $v_{\max }(\mathrm{KBr}) / \mathrm{cm}^{-1} 3434,3349,3193,3050$, 2972, 2851, 1725, 1621, 1551, 1425, 1313, 1238, 1209, 1141, 1021, $1021,971,858,772,706,564 ; \delta_{\mathrm{H}}\left(\left(\mathrm{CD}_{3}\right)_{2} \mathrm{SO}\right) 1.21(3 \mathrm{H}, \mathrm{t}, J=7.1)$, $2.40(3 \mathrm{H}, \mathrm{s}), 3.64(2 \mathrm{H}, \mathrm{s}), 4.13(2 \mathrm{H}, \mathrm{q}, J=7.1), 6.00\left(2 \mathrm{H}, \mathrm{s}, \mathrm{NH}_{2}\right)$, $11.91(1 \mathrm{H}$, br s, $\mathrm{NOH}), 12.10(1 \mathrm{H}, \mathrm{br} \mathrm{s}, \mathrm{NH}) ; \delta_{\mathrm{C}}\left(\left(\mathrm{CD}_{3}\right)_{2} \mathrm{SO}\right) 12.8$, 14.3, 19.6, 60.9, 88.4, 150.2, 150.7, 160.2, 164.2, 167.1; HREIMS: calcd for $\mathrm{C}_{10} \mathrm{H}_{14} \mathrm{~N}_{4} \mathrm{O}_{4} \mathrm{~S}\left(\mathrm{M}^{+}\right)$; 286.07358 found 286.07359 .

(b) Microwave method. 6-Amino-2-methylsulfanyl-3Hpyrimidin-4-one 16b (0.5 g, $3.2 \mathrm{mmol})$ was dissolved in dry DMF $(4 \mathrm{ml})$ in a $10 \mathrm{ml}$ microwave tube. Triethylamine $(0.32 \mathrm{~g}, 3.2 \mathrm{mmol})$ and a solution of ethyl bromopyruvate oxime $(0.7 \mathrm{~g}, 3.5 \mathrm{mmol})$ in dry DMF ( $2 \mathrm{ml})$ was added. The tube was placed in a microwave and irradiated at $50{ }^{\circ} \mathrm{C}$ at $18 \mathrm{psi}$ for $30 \mathrm{~min}$. The solution was evaporated under reduced pressure and the residue was dissolved in a solution of ethyl acetate and methanol $(4: 1,10 \mathrm{ml})$. The resulting solution was absorbed onto a silica gel chromatography column and eluted with $100 \%$ ethyl acetate, increasing the polarity up to 4:1 ethyl acetate/methanol solution. The desired product was crystallised from ethyl acetate and hexane, and dried at $0.1 \mathrm{~mm} \mathrm{Hg} / 40{ }^{\circ} \mathrm{C}$ to yield the desired product $17(0.46 \mathrm{~g}$, $1.6 \mathrm{mmol}, 36 \%)$ as a pale yellow solid. Analytical data were identical to those reported above.

2-Methylsulfanyl-4-oxo-4,7-dihydro-3H-pyrrolo[2,3- $d$ ]pyrimidine-6-carboxylic acid ethyl ester 18. 3-(4-Amino-2-methylsul- fanyl-6-oxo-1,6-dihydropyrimidin-5-yl)-2-hydroxyimino-propionic acid ethyl ester $17(0.09 \mathrm{~g}, 0.3 \mathrm{mmol})$ was suspended in a mixture of ethanol $(20 \mathrm{ml})$, water $(20 \mathrm{ml})$ and concentrated hydrochloric acid (4 drops). The solution was stirred for $10 \mathrm{~min}$ prior to benzaldehyde $(4 \mathrm{ml})$ being added and the mixture being heated to reflux under nitrogen until the reaction was complete as shown by TLC. The solvent was removed under reduced pressure using co-evaporation with toluene/ethanol $(1: 1,10 \mathrm{ml})$ to remove residual water. The residue was suspended in ethyl acetate/diethyl ether $(1: 1,15 \mathrm{ml})$ and filtered to afford the title compound 18 as a yellow solid $(0.04 \mathrm{~g}, 0.16 \mathrm{mmol}, 54 \%) ; \mathrm{mp}$ $>230{ }^{\circ} \mathrm{C} ; v_{\max }(\mathrm{KBr}) / \mathrm{cm}^{-1} 3349,1719,1639,1577,1458,1240$, $695 ; \delta_{\mathrm{H}}\left(\left(\mathrm{CD}_{3}\right)_{2} \mathrm{SO}\right) 1.13(\mathrm{t}, 3 \mathrm{H}, J=7.1), 2.56(\mathrm{~s}, 3 \mathrm{H}), 4.27(\mathrm{q}, 2 \mathrm{H}$, $J=7.1), 7.13(\mathrm{~s}, 1 \mathrm{H}), 12.29$ (s, 1H, NH), 12.59 (s, 1H, NH).

2-Methylsulfanyl-4-oxo-4,7-dihydro-3 $\boldsymbol{H}$-pyrrolo[2,3- $d$ ]pyrimidine-6-carboxylic acid 19. 2-Methylsulfanyl-4-oxo-4,7-dihydro$3 H$-pyrrolo[2,3- $d$ ] pyrimidine-6-carboxylic acid ethyl ester $\mathbf{1 8}$ $(0.030 \mathrm{~g}, 0.12 \mathrm{mmol})$, lithium hydroxide $(0.02 \mathrm{mg}, 0.84 \mathrm{mmol})$, in water $(5 \mathrm{ml})$ and THF $(1 \mathrm{ml})$ were stirred together at room temperature under nitrogen. The reaction was left stirring for 4 $\mathrm{d}$ after which the solvents were removed by evaporation under reduced pressure. Water $(10 \mathrm{ml})$ was added and the $\mathrm{pH}$ adjusted to 1-2 using hydrochloric acid solution (1 M). The solvents were removed by evaporation under reduced pressure, leaving a solid product 19 as a white solid $(0.02 \mathrm{~g}, 0.1 \mathrm{mmol}, 88 \%) ; \mathrm{mp}>230{ }^{\circ} \mathrm{C}$; $v_{\max }(\mathrm{KBr}) / \mathrm{cm}^{-1} 3437,3257,3193,2956,2431,1659,1563,1496$, $1424,1385,1243,1168,1139,983,771,671,531 ; \delta_{\mathrm{H}}\left(\left(\mathrm{CD}_{3}\right)_{2} \mathrm{SO}\right)$ $2.57(3 \mathrm{H}, \mathrm{s}), 6.91(1 \mathrm{H}, \mathrm{s}), 12.17(1 \mathrm{H}, \mathrm{s}, \mathrm{NH}), 12.43(1 \mathrm{H}, \mathrm{s}, \mathrm{NH})$, $12.68\left(1 \mathrm{H}\right.$, br s); HREIMS: calcd for $\mathrm{C}_{8} \mathrm{H}_{7} \mathrm{~N}_{3} \mathrm{O}_{3} \mathrm{~S}\left(\mathrm{M}^{+}\right) ; 225.0208$ found 225.0211 .

6-Amino-2-(benzylthio)-5-(2-nitrocyclohexyl)pyrimidin-4(3H)one 23 and 2-benzylsulfanyl-3,5,6,7,8,9-hexahydro-1,3,9-triazafluoren-4-one 24. 6-Amino-2-(benzylthio)pyrimidin-4(3H)-one $3(0.29 \mathrm{~g}, 1.23 \mathrm{mmol})$ was suspended in acetonitrile $(20 \mathrm{ml})$. To this was added 1,8-diazabicyclo[5.4.0]undec-7-ene (DBU) $(374 \mu \mathrm{l}$, $0.38 \mathrm{~g}, 2.50 \mathrm{mmol}, 2.0 \mathrm{eq}$.) and the mixture became a clear solution. Nitrocyclohexene ( $180 \mu \mathrm{l}, 0.2 \mathrm{~g}, 1.60 \mathrm{mmol}, 1.3 \mathrm{eq}$.$) was added$ and the mixture was stirred at $80{ }^{\circ} \mathrm{C}$ for $4 \mathrm{~d}$. The mixture was then concentrated under reduced pressure and the crude material was purified by column chromatography using ethyl acetate/hexane (1:2) as eluant. 23 was obtained as a light brown solid $(0.055 \mathrm{~g}$, $0.15 \mathrm{mmol}, 12 \%)$; mp $152-150{ }^{\circ} \mathrm{C} ; v_{\max }(\mathrm{KBr}) / \mathrm{cm}^{-1} 3494,3359$, 3049, 2927, 2862, 1614, 1576, 1454, 1405, 1376, 1312, 1241, 1208, $1104,1070,767,697 ; \delta_{\mathrm{H}}\left(\left(\mathrm{CD}_{3}\right)_{2} \mathrm{SO}\right) 1.61-1.63(2 \mathrm{H}, \mathrm{m}), 1.72-$ $1.74(2 \mathrm{H}, \mathrm{m}), 2.09-2.11(1 \mathrm{H}, \mathrm{m}), 2.14-2.17(2 \mathrm{H}, \mathrm{m}), 2.25-2.28$ $(2 \mathrm{H}, \mathrm{m}), 4.34(2 \mathrm{H}, \mathrm{s}), 6.96\left(2 \mathrm{H}, \mathrm{br} \mathrm{s}, \mathrm{NH}_{2}\right), 7.20-7.31(3 \mathrm{H}$, $\mathrm{m}, \mathrm{Ph}), 7.42-7.44(2 \mathrm{H}, \mathrm{m}), 10.65(1 \mathrm{H}, \mathrm{s}, \mathrm{NH}) ; \delta_{\mathrm{C}}\left(\left(\mathrm{CD}_{3}\right)_{2} \mathrm{SO}\right)$ 20.6, 22.0, 22.2, 25.8, 27.9, 33.9, 97.8, 110.9, 126.8, 128.3, 128.9, 138.6, 157.7, 163.4, 166.1; MS (electrospray) $\mathrm{M}^{+}+1=361$. The hexahydrotriazafluorenone $\mathbf{2 4}$ was obtained as an off-white solid $(0.096 \mathrm{~g}, 0.31 \mathrm{mmol}, 25 \%) ; \mathrm{mp}>230^{\circ} \mathrm{C} ; v_{\max }(\mathrm{KBr}) / \mathrm{cm}^{-1} 3414$, $3130,2930,2849,1647,1546,1477,1380,1334,1246,1192,1133$, $990,772,694 ; \delta_{\mathrm{H}}\left(\left(\mathrm{CD}_{3}\right)_{2} \mathrm{SO}\right) 1.68-1.81(4 \mathrm{H}, \mathrm{m}), 2.48-2.51(2 \mathrm{H}$, $\mathrm{m}), 2.61-2.63(2 \mathrm{H}, \mathrm{m}), 4.39(2 \mathrm{H}, \mathrm{s}), 7.23-7.33(3 \mathrm{H}, \mathrm{m}),, 7.42-7.44$ $(2 \mathrm{H}, \mathrm{m}), 11.33(1 \mathrm{H}, \mathrm{s}, \mathrm{NH}), 11.83(1 \mathrm{H}, \mathrm{br} \mathrm{s}, \mathrm{NH}) ; \delta_{\mathrm{C}}\left(\left(\mathrm{CD}_{3}\right)_{2} \mathrm{SO}\right)$ $21.8,22.0,22.7,33.5,102.6,111.2,127.2,127.7,128.4,129.0$, 137.5, 147.4, 151.4, 159.0; HREIMS: calcd for $\mathrm{C}_{17} \mathrm{H}_{17} \mathrm{~N}_{3} \mathrm{OS}\left(\mathrm{M}^{+}\right)$; 311.1092 found 311.1094 . 
6-Amino-2-(benzylsulfanyl)-5-[1-(4-bromophenyl)-2-nitroethyl]4(3H)-pyrimidinone 25a. To a mixture of 6-amino-2(benzylsulfanyl)-4(3H)-pyrimidinone $3(0.4 \mathrm{~g}, 1.72 \mathrm{mmol})$ in water $(10 \mathrm{ml})$ was added $N, N, N$-trimethyl(phenyl)methanaminium hydroxide $(40 \%$ solution in water, $1 \mathrm{ml}, 2.6 \mathrm{mmol})$. The mixture was stirred for $5 \mathrm{~min}$ and then 1-bromo-4-[(E)-2nitroethenyl]benzene $(0.39 \mathrm{~g}, 1.72 \mathrm{mmol})$ and ethyl acetate $(10 \mathrm{ml})$ were added. The resulting mixture was stirred in an oil bath at $70{ }^{\circ} \mathrm{C}$ for $4 \mathrm{~h}$, whereafter ethyl acetate $(30 \mathrm{ml})$ was added, and the organic layer was separated, dried, and concentrated under reduced pressure. The residue was purified by column chromatography (silica gel/ethyl acetate: $n$-hexane $=1: 3$ to $1: 1$ ) to give the product $25 \mathrm{a}$ as a brown solid $(0.57 \mathrm{~g}, 1.23 \mathrm{mmol}$, $72 \%$ ), mp $93-95{ }^{\circ} \mathrm{C}$. Found: C, 65.63; H, 4.29; N, 10.84; S, 8.38; $\mathrm{C}_{19} \mathrm{H}_{17} \mathrm{BrN}_{4} \mathrm{O}_{3} \mathrm{~S}$ requires $\mathrm{C}, 66.10 ; \mathrm{H}, 4.71 ; \mathrm{N}, 11.56 ; \mathrm{S}, 8.82 \%$. $v_{\max }$ $(\mathrm{KBr}) / \mathrm{cm}^{-1} 3489,3389,1610,1545\left(\mathrm{CNO}_{2}\right), 1488,1420,1374$, $1222,1073,975,698 ; \delta_{\mathrm{H}}\left(\left(\mathrm{CD}_{3}\right)_{2} \mathrm{SO}\right) 4.33(2 \mathrm{H}, \mathrm{s}), 4.60(1 \mathrm{H}, \mathrm{t}, J=$ 7.4), 5.29-5.46 (2H, m), $6.79\left(2 \mathrm{H}\right.$, br s, $\left.\mathrm{NH}_{2}\right), 7.22-7.45(9 \mathrm{H}, \mathrm{m})$, $11.81(1 \mathrm{H}, \mathrm{br} \mathrm{s}) ; \delta_{\mathrm{C}}\left(\left(\mathrm{CD}_{3}\right)_{2} \mathrm{SO}\right) 38.5(2 \mathrm{C}), 74.8,90.9,127.2,128.4$, 129.1, 130.0, 130.9, 137.6, 139.7, 158.2, 160.0, 162.2; HREIMS: calcd for $\mathrm{C}_{19} \mathrm{H}_{17}{ }^{81} \mathrm{BrN}_{4} \mathrm{O}_{3} \mathrm{~S}(\mathrm{M}) ; 463.0264$, found 463.0271.

Similarly prepared were: 6-amino-2-(benzylsulfanyl)-5-(2-nitro1-phenylethyl)-4(3H)-pyrimidinone $\mathbf{2 5 b}$, 6-amino-2-(benzylsulfanyl)-5-[1-(4-methoxyphenyl)-2-nitroethyl]-4(3H)-pyrimidinone 25c, and 6-amino-2-(benzylsulfanyl)-5-\{2-nitro-1-[2-(trifluoromethyl)phenyl]ethyl $\}-4(3 H)$-pyrimidinone 25d, the details of which can be found in the Supplementary Information.

\section{2-(Benzylsulfanyl)-5-(4-bromophenyl)-3,7-dihydro-4H- pyrrolo[2,3- $d]$ pyrimidin-4-one 26a.}

(a) Titanium (III) chloride reaction. 6-Amino-2-(benzylsulfanyl)-5-[1-(4-bromophenyl)-2-nitroethyl]-4(3H)-pyrimidinone 25 a $(0.33 \mathrm{~g}, 0.72 \mathrm{mmol})$ was dissolved in methanol $(10 \mathrm{ml})$ and treated with one equivalent of sodium methoxide $(38.9 \mathrm{mg})$. A titanium(III) chloride solution was prepared separately by adding an aqueous solution of ammonium acetate $(3.3 \mathrm{~g}, 43 \mathrm{mmol})$ in water $(5 \mathrm{ml})$ to titanium(III) chloride $(5.6 \mathrm{ml}, 4.3 \mathrm{mmol}$, $10 \%$ solution in hydrochloric acid) under nitrogen. The prepared titanium(III) chloride solution was then added carefully to the anionic solution under nitrogen with vigorous stirring. The colour changed slowly from brown to yellow. The mixture was stirred overnight at room temperature then poured into ethyl acetate $(20 \mathrm{ml})$ and separated into two phases. The aqueous phase was extracted with ethyl acetate $(30 \mathrm{ml} \times 3)$. The organic extracts were combined, washed with $5 \%$ sodium bicarbonate $(20 \mathrm{ml})$ and with brine $(20 \mathrm{ml})$, then dried with anhydrous magnesium sulfate, and concentrated under reduced pressure. The residue was recrystallised from ethyl acetate and $n$-hexane to afford the product 26a as a yellow solid $(0.14 \mathrm{~g}, 0.34 \mathrm{mmol}, 47 \%)$. The physical and spectroscopic data were identical to those recorded below.

(b) Tin(II) chloride reaction. To a mixture of 6-amino-2(benzylsulfanyl)-5-[1-(4-bromophenyl)-2-nitroethyl]-4(3H)pyrimidinone 25a $(0.1 \mathrm{~g}, 0.22 \mathrm{mmol})$ in ethyl acetate $(15 \mathrm{ml})$ was added tin(II) chloride dihydrate $(0.15 \mathrm{~g}, 0.65 \mathrm{mmol})$. The resulting mixture was stirred in an oil bath at $85^{\circ} \mathrm{C}$ for 24 hours then poured into ethyl acetate $(20 \mathrm{ml})$ and washed with saturated aqueous sodium bicarbonate $(20 \mathrm{ml}), 1 \%$ hydrochloric acid $(10 \mathrm{ml})$ and with brine $(20 \mathrm{ml})$, then dried with anhydrous magnesium sulfate, and concentrated. The residue was purified by column chromatography (silica gel/ethyl acetate: $n$-hexane $=1: 1$ to ethyl acetate $100 \%)$ to give the product $25 \mathrm{a}$ as a yellow solid $(23 \mathrm{mg}$, $0.056 \mathrm{mmol}, 25 \%) ; \mathrm{mp} 270-272{ }^{\circ} \mathrm{C} . v_{\max }(\mathrm{KBr}) / \mathrm{cm}^{-1} 3251,2819$, $1649,1431,1212,1073,1010,970,782,729 ; \delta_{\mathrm{H}}\left(\left(\mathrm{CD}_{3}\right)_{2} \mathrm{SO}\right) 4.44$ $(2 \mathrm{H}, \mathrm{s}), 7.39(1 \mathrm{H}, \mathrm{d}, J=2.5), 7.46-7.51(4 \mathrm{H}, \mathrm{m}), 12.08(1 \mathrm{H}, \mathrm{s})$, $12.15(1 \mathrm{H}, \mathrm{s}) ; \delta_{\mathrm{C}}\left(\left(\mathrm{CD}_{3}\right)_{2} \mathrm{SO}\right) 33.5,101.2,118.1,118.7,118.8,127.3$ (2C), 128.5, 129.1, 129.7, 130.2, 133.5, 137.3 (2C), 149.5, 153.8, 159.1; HREIMS: calcd for $\mathrm{C}_{19} \mathrm{H}_{14}{ }^{79} \mathrm{BrN}_{3} \mathrm{OS}\left(\mathrm{M}^{+}\right) ; 411.0041$ found 411.0042 .

Similarly prepared were: 2-(benzylsulfanyl)-5-phenyl-3,7dihydro-4H-pyrrolo[2,3- $d]$ pyrimidin-4-one $\quad 26 \mathbf{b}, \quad$ 2-(benzylsulfanyl)-5-(4-methoxyphenyl)-3,7-dihydro-4H-pyrrolo[2,3-d]pyrimidin-4-one 26c, and 2-(benzylsulfanyl)-5-[2-(trifluoromethyl)phenyl]-3,7-dihydro-4H-pyrrolo[2,3-d]pyrimidin-4-one 26d, details of which can be found in the Supplementary Information.

6-Amino-2-(methylsulfanyl)-5-(2-nitro-1-phenylethyl)-4(3H)pyrimidinone 27. To a mixture of 6-amino-2-(methylsulfanyl)-4(3H)-pyrimidinone 16b (2 $\mathrm{g}, 12.7 \mathrm{mmol})$ in water (40 ml) was added $N, N, N$-trimethyl(phenyl)methanaminium hydroxide ( $40 \%$ solution in water, $6 \mathrm{ml})$. The mixture was stirred for $10 \mathrm{~min}$ at $60{ }^{\circ} \mathrm{C}$ and then $[(E)$-2-nitroethenyl]benzene $(2 \mathrm{~g}$, $13.4 \mathrm{mmol})$ and ethyl acetate $(40 \mathrm{ml})$ were added. The resulting mixture was stirred in an oil bath at $60{ }^{\circ} \mathrm{C}$ for $3 \mathrm{~h}$. The organic layer was separated, washed with brine $(20 \mathrm{ml})$, dried, and concentrated under reduced pressure. The residue was purified by column chromatography (silica gel/ethyl acetate: $n$-hexane $=$ $2: 1$ to $1: 1)$ to give the product 27 as a purple solid $(1.0 \mathrm{~g}$, $3.3 \mathrm{mmol}, 26 \%)$; $\mathrm{mp} 107-110{ }^{\circ} \mathrm{C} ; \mathrm{v}_{\max }(\mathrm{KBr}) / \mathrm{cm}^{-1} 3478,3389$, 3214, 1613, 1574, $1546\left(\mathrm{C}-\mathrm{NO}_{2}\right), 1419,1377,1220,971,757,699$; $\delta_{\mathrm{H}}\left(\left(\mathrm{CD}_{3}\right)_{2} \mathrm{SO}\right) 2.40(3 \mathrm{H}, \mathrm{s}), 4.60(1 \mathrm{H}, \mathrm{t}, J=7.7), 5.25-5.52(2 \mathrm{H}$, $\mathrm{m}), 6.04\left(2 \mathrm{H}, \mathrm{s}, \mathrm{NH}_{2}\right), 7.16-7.47(5 \mathrm{H}, \mathrm{m}, \mathrm{Ph}), 11.78(1 \mathrm{H}, \mathrm{s}, \mathrm{CH})$; $\delta_{\mathrm{C}}\left(\left(\mathrm{CD}_{3}\right)_{2} \mathrm{SO}\right) 12.4,38.9,77.1,91.1,126.6,128.1,127.7,140.2$, 159.0, 160.1, 162.1; HRFABMS: found $329.0693\left(\mathrm{M}+\mathrm{Na}^{+}\right)$; $\mathrm{C}_{13} \mathrm{H}_{14} \mathrm{~N}_{4} \mathrm{O}_{3} \mathrm{SNa}^{+}$requires 329.0684 .

2-(Methylsulfanyl)-5-phenyl-3, 7-dihydro-4H -pyrrolo $[2,3-d]$ pyrimidin-4-one 28. To a mixture of 6-amino-2-(methylsulfanyl)4(3H)-pyrimidinone 27 (2 g, $12.7 \mathrm{mmol})$ in water $(40 \mathrm{ml})$ was added $N, N, N$-trimethyl(phenyl)methanaminium hydroxide $(40 \%$ solution in water, $6 \mathrm{ml}$ ). The mixture was stirred for $10 \mathrm{~min}$ at $60{ }^{\circ} \mathrm{C}$ and then $[(E)$-2-nitroethenyl]benzene $(2 \mathrm{~g}, 13.4 \mathrm{mmol})$ and ethyl acetate $(40 \mathrm{ml})$ were added. The resulting mixture was stirred in an oil bath at $60{ }^{\circ} \mathrm{C}$ for $3 \mathrm{~h}$. The precipitate was collected by filtration, washed with water $(20 \mathrm{ml})$ and $n$-hexane $(20 \mathrm{ml})$, to afford the required product $\mathbf{2 8}$ as a light purple solid $(0.92 \mathrm{~g}$, $3.6 \mathrm{mmol}, 28 \%) ; \mathrm{mp}>260{ }^{\circ} \mathrm{C}$. $v_{\max }(\mathrm{KBr}) / \mathrm{cm}^{-1} 3417,3170,3050$, 2906, 2829, 1655, 1584, 1523, 1429, 1294, 1207, 1095, 970, 752, 692; $\delta_{\mathrm{H}}\left(\left(\mathrm{CD}_{3}\right)_{2} \mathrm{SO}\right) 2.52(3 \mathrm{H}, \mathrm{s}), 7.15-7.19(1 \mathrm{H}, \mathrm{m}), 7.27(1 \mathrm{H}, \mathrm{d}, J=$ 2.2), 7.29-7.32 (2H, m), $7.91(2 \mathrm{H}, \mathrm{m}), 11.97(1 \mathrm{H}, \mathrm{s}), 12.10(1 \mathrm{H}$, $\mathrm{s}) ; \delta_{\mathrm{C}}\left(\left(\mathrm{CD}_{3}\right)_{2} \mathrm{SO}\right) 12.8,101.0,117.5,119.9,125.7,127.7,127.9$, 134.2, 149.6, 154.7, 159.0; HREIMS: calcd for $\mathrm{C}_{13} \mathrm{H}_{11} \mathrm{~N}_{3} \mathrm{OS}\left(\mathrm{M}^{+}\right)$; 258.0701 found 258.0699 .

2-(Benzylamino)-5-phenyl-3,7-dihydro-4H-pyrrolo[2,3-d]pyrimidin-4-one 31a. To a mixture of 2-(methylsulfanyl)-5phenyl-3,7-dihydro-4H-pyrrolo[2,3- $d$ ]pyrimidin-4-one $28(0.2 \mathrm{~g}$, $0.78 \mathrm{mmol})$ in dimethylformamide $(5 \mathrm{ml})$ was added 3chlorobenzenecarboperoxoic acid (77\%, $0.52 \mathrm{~g}, 2.3 \mathrm{mmol})$. The 
resulting mixture was stirred for $4 \mathrm{~h}$ at $3{ }^{\circ} \mathrm{C}$. Dimethylformamide was evaporated under vacuum. The resulting solid was washed with ether $(50 \mathrm{ml})$, to afford the crude sulfone as a light pink solid ( $0.18 \mathrm{~g}, 80 \%$, confirmed by LCMS: $\mathrm{M}+1=290)$. The crude sulfone intermediate was heated with benzylamine $(1 \mathrm{ml})$ in a sealed tube for $15 \mathrm{~h}$ at $100{ }^{\circ} \mathrm{C}$. Benzylamine was removed under vacuum and the residue was purified by column chromatography (silica gel/ethyl acetate: $n$-hexane $=2: 1$ to ethyl acetate $100 \%$ ) to afford the required product 31a as a yellow solid $(88 \mathrm{mg}$, $0.28 \mathrm{mmol}, 36 \%)$; mp $278-280{ }^{\circ} \mathrm{C} . v_{\max }(\mathrm{KBr}) / \mathrm{cm}^{-1} 3412,3197$, $2785,1654,1477,1292,1100,749,694,655 ; \delta_{\mathrm{H}}\left(\left(\mathrm{CD}_{3}\right)_{2} \mathrm{SO}\right) 4.49$ $(2 \mathrm{H}, J=5.8), 6.51(1 \mathrm{H}, \mathrm{t}, J=5.8), 6.99(1 \mathrm{H}, \mathrm{d}, J=2.4), 7.11-$ $7.34(8 \mathrm{H}, \mathrm{m}), 7.91-7.93(2 \mathrm{H}, \mathrm{m}), 10.30(1 \mathrm{H}, \mathrm{br} \mathrm{s}), 11.34(1 \mathrm{H}, \mathrm{br} \mathrm{s})$; $\delta_{\mathrm{C}}\left(\left(\mathrm{CD}_{3}\right)_{2} \mathrm{SO}\right) 43.7,97.3,115.2,119.7,126.9,125.2,126.3,127.0$, 127.4, 127.8, 139.3, 134.8, 151.5, 152.1, 159.0; HREIMS: calcd for $\mathrm{C}_{19} \mathrm{H}_{16} \mathrm{~N}_{4} \mathrm{O}\left(\mathrm{M}^{+}\right)$; 316.1324 found 316.1326 .

Similarly prepared were: 5-phenyl-2-(1-pyrrolidinyl)-3,7dihydro-4 $H$-pyrrolo[2,3- $d$ ]pyrimidin-4-one 31 b, and 2-anilino5-phenyl-3,7-dihydro-4 $H$-pyrrolo[2,3-d]pyrimidin-4-one 31c, the details of which can be found in the Supplementary Information.

Ethyl 2-(benzylamino)-4-oxo-4,7-dihydro-3 $H$-pyrrolo[2,3- $d]$ pyrimidine-6-carboxylate 29. To a mixture of 2-methylsulfanyl-4oxo-4,7-dihydro-3 $H$-pyrrolo[2,3- $d$ ]pyrimidine-6-carboxylic acid ethyl ester $\mathbf{X}(0.16 \mathrm{~g}, 0.63 \mathrm{mmol})$ in dimethylformamide $(5 \mathrm{ml})$ was added 3-chlorobenzenecarboperoxoic acid $(77 \%, 0.42 \mathrm{~g}$, $1.9 \mathrm{mmol}$ ). The resulting mixture was stirred for $4 \mathrm{~h}$ at room temperature. Dimethylformamide was evaporated under reduced pressure. The resulting solid was washed with ether $(50 \mathrm{ml})$, to afford the crude sulfone as a brown solid $(0.13 \mathrm{~g}, 73 \%$, confirmed by $\mathrm{MS}(\mathrm{ES}): \mathrm{M}+1=286)$. The crude sulfone intermediate was heated with benzylamine $(1 \mathrm{ml})$ in a sealed tube for $15 \mathrm{~h}$ at $100{ }^{\circ} \mathrm{C}$. Benzylamine was removed under vacuum and the residue was purified by column chromatography (silica gel/ethyl acetate $100 \%$ ) and separate from the di-substituted product by HPLC to afford the required product 29 as a white solid $(24 \mathrm{mg}$, $0.077 \mathrm{mmol}, 12 \%$ ); $\mathrm{mp}>250{ }^{\circ} \mathrm{C}$. Found: C, 61.9; H, 5.2; N, 17.6; $\mathrm{C}_{16} \mathrm{H}_{16} \mathrm{~N}_{4} \mathrm{O}_{3}$ requires $\mathrm{C}, 61.5 ; \mathrm{H}, 5.2 ; \mathrm{N}, 17.9 \%$. $v_{\max }(\mathrm{KBr}) / \mathrm{cm}^{-1}$ 3422, 3120, 2978, 1662, 1615, 1552, 1522, 1410, 1303, 1240, 1196, 1026, 776, 696, 548; $\delta_{\mathrm{H}}\left(\left(\mathrm{CD}_{3}\right)_{2} \mathrm{SO}\right) 1.27(3 \mathrm{H}, \mathrm{t}, J=7.1), 4.17$ $(2 \mathrm{H}, \mathrm{q}, J=7.1), 4.49(2 \mathrm{H}, \mathrm{d}, J=5.8), 6.79(1 \mathrm{H}, \mathrm{t}, J=5.8), 6.91$ $(1 \mathrm{H}, \mathrm{d}, J=2.2), 7.22-7.34(5 \mathrm{H}, \mathrm{m}), 10.49(1 \mathrm{H}, \mathrm{s}), 11.91(1 \mathrm{H}, \mathrm{s})$; $\delta_{\mathrm{C}}\left(\left(\mathrm{CD}_{3}\right)_{2} \mathrm{SO}\right) 14.2,43.7,59.7,101.9,109.7,120.3,127.0,127.2$, 128.4, 139.0, 152.4, 153.0, 158.8, 160.3; HR-FABMS: calcd for $\mathrm{C}_{16} \mathrm{H}_{16} \mathrm{~N}_{4} \mathrm{O}_{3}\left(\mathrm{M}+\mathrm{H}^{+}\right)$; 313.1301 found 313.1311 .

$\mathrm{N}$-Benzyl-2-(benzylamino)-4-oxo-4,7-dihydro-3H-pyrrolo[2,3$\boldsymbol{d}$ lpyrimidine-6-carboxamide 30. To a mixture of 2-methylsulfanyl-4-oxo-4,7-dihydro-3 $H$-pyrrolo[2,3- $d$ ]pyrimidine-6-carboxylic acid ethyl ester $\mathbf{X}(0.16 \mathrm{~g}, 0.63 \mathrm{mmol})$ in dimethylformamide $(5 \mathrm{ml})$ was added 3 -chlorobenzenecarboperoxoic acid $(77 \%, 0.42 \mathrm{~g}$, $1.9 \mathrm{mmol})$. The resulting mixture was stirred for $4 \mathrm{~h}$ at room temperature. Dimethylformamide was evaporated under reduced pressure. The resulting solid was washed with ether $(50 \mathrm{ml})$, to afford the crude sulfone as a brown solid $(0.13 \mathrm{~g}, 73 \%$, confirmed by $\mathrm{MS}(\mathrm{ES})$ : $\mathrm{M}+1=286$ ). The crude sulfone intermediate was heated with benzylamine $(1 \mathrm{ml})$ in a sealed tube for $15 \mathrm{~h}$ at $100{ }^{\circ} \mathrm{C}$. Benzylamine was removed under reduced pressure and the residue was purified by column chromatography (silica gel/ethyl acetate $100 \%$ ) and separated from the mono-substituted product by HPLC (C18 Luna column eluting with a water/0.1\% trifluoroacetic acid and acetonitrile $/ 0.1 \%$ trifluoroacetic acid gradient) to afford the required product as a white solid $\mathbf{3 0}(24 \mathrm{mg}$, $0.064 \mathrm{mmol}, 10 \%) ; \mathrm{mp}>250^{\circ} \mathrm{C} . v_{\max }(\mathrm{KBr}) / \mathrm{cm}^{-1} 3422,1613,1544$, $1451,1292,1245,1215,784,749,696 ; \delta_{\mathrm{H}}\left(\left(\mathrm{CD}_{3}\right)_{2} \mathrm{SO}\right) 4.40(2 \mathrm{H}, \mathrm{d})$, $J=5.9), 4.47(2 \mathrm{H}, \mathrm{d}, J=5.8), 6.65(1 \mathrm{H}, \mathrm{t}, J=5.8), 7.01(1 \mathrm{H}$, $J=2.3), 7.21-7.39(10 \mathrm{H}, \mathrm{m}, \mathrm{Ph}), 8.53(1 \mathrm{H}, J=6.0), 10.37(1 \mathrm{H}$, s), $11.54(1 \mathrm{H}, \mathrm{s}) ; \delta_{\mathrm{C}}\left(\left(\mathrm{CD}_{3}\right)_{2} \mathrm{SO}\right) 42.0,43.8,101.2,105.0,124.4$, $126.7,126.9,127.2,127.3,128.2,128.3,139.1,139.8,151.5,152.4$, 158.9, 160.3; HREIMS: calcd for $\mathrm{C}_{16} \mathrm{H}_{16} \mathrm{~N}_{4} \mathrm{O}_{3}\left(\mathrm{M}^{+}\right) ; 374.1618$ found 374.1617 .

\section{Biological assay}

Pteridine reductase was purified as described. ${ }^{24}$ The enzyme (15 mg/ml, $50 \mathrm{mM}$ Tris. $\mathrm{HCl}, 250 \mathrm{mM} \mathrm{NaCl}, 20 \%$ (v/v) glycerol, $\mathrm{pH}$ 7.5) was flash frozen in liquid $\mathrm{N}_{2}$ and stored at $-20{ }^{\circ} \mathrm{C}$ until required. Potential inhibitors were dissolved at $100 \mathrm{mM}$ in DMSO, while the substrate dihydrobiopterin was dissolved to $10 \mathrm{mM}$ in $0.1 \mathrm{M} \mathrm{NaOH}$. Inhibition assays were performed by adding increasing concentrations of inhibitor with the DMSO concentration kept below the level affecting enzyme activity (1\%). NADPH oxidation was followed, at $340 \mathrm{~nm}$, in continuous assays executed in a Beckman DU640 spectrophotometer. $\mathrm{IC}_{50}$ and $\mathrm{Ki}$ values were determined from dose-response plots using SigmaPlot (Systat Software Inc).

Cell based assays for trypanocidal activity were carried out against the blood stream form of Trypanosoma brucei brucei. ${ }^{41}$ Mammalian cell toxicity was investigated using the normal cell lines HS27 (human fibroblasts), L929 (murine fibroblasts) and H9C2 (murine myoblasts), and the cancer cell lines A2780 (human ovarian carcinoma) and SHSY5Y (human neuroblastoma) using the Alamar blue microplate method. ${ }^{44}$ The assays were conducted in 96 well microplates with incubation at $37^{\circ} \mathrm{C}$ under a humidified $5 \% \mathrm{CO}_{2}$ atmosphere for $24 \mathrm{~h}$ for mammalian cells and $48 \mathrm{~h}$ for trypanosomes. Fluorescence was detected using a Wallac Victor 2 multilabel plate reader (excitation $560 \mathrm{~nm}$, emission $590 \mathrm{~nm}$ ) giving $\%$ of control values. Minimum inhibitory concentration values (MICs) were obtained for compounds showing less than $20 \%$ of control values against $T$. b. brucei.

\section{Crystal data for $6 \mathrm{c.0.8MeOH}$}

$\mathrm{C}_{16.8} \mathrm{H}_{19.2} \mathrm{~N}_{4} \mathrm{O}_{4.8}, M_{r}=353.96$, triclinic, space group $\mathrm{P} \overline{1}, a=$ 7.1471(3), $b=10.1809(4), c=12.3149(5) \AA, \alpha=81.282(3)$, $\beta=77.534(2), \gamma=81.436(3)^{\circ}, V=858.56(6) \AA^{3}, Z=2, \lambda=$ $0.71073 \AA$ A $\mu=0.102 \mathrm{~mm}^{-1}, T=123 \mathrm{~K}$; Data quality was impaired by generic twinning. Methanol solvate was treated as disordered over two sites with occupancies of 0.5 and 0.3 .15464 reflections, 3900 unique, $\mathrm{R}_{\text {int }} 0.040$. Final refinement ${ }^{45}$ to convergence on $F^{2}$ gave $R=0.0528$ ( $F, 2695$ obs. data only) and $R_{\mathrm{w}}=0.1447\left(F^{2}\right.$, all data), GOF $=1.039$. CCDC reference number 705654. $\dagger$

\section{Notes and references}

1 G. H. Hitchings and J. A. Burchall, Adv. Enzymol., 1965, 27, 417; C. W. Carreras and D. V. Santi, Annu. Rev. Biochem., 1995, 64, 721; J. N. McCormick, in Comprehensive Medicinal Chemistry, vol 2, ed. P. G. Sammes, Pergamon, Oxford, 1990, pp. 272-290; F. Rebeille, D. Macherel, J. M. Mouillon, J. Garin and R. Douce, EMBO J., 1997, 16, 947; G. M. Brown and J. M. Williamson, in Cellular and Molecular 
Biology, vol 1, ed. F. C. Neidhardt, American Society of Microbiology, 1997; C. A. Nichol, G. K. Smith and S. S. Gross, Annu. Rev. Biochem., 1985, 54, 729-764; D. B. Bolstad, E. S. D. Bolstad, D. L. Wright and A. C. Anderson, Expert Opinion on Therapeutic Patents, 2008, 18, 143.

2 C. L. Gibson, S. La, Rosa, K. Ohta, P. H. Boyle, F. Leurquin, A. Lemaçon and C. J. Suckling, Tetrahedron, 2004, 60, 943.

3 C. L. Gibson, S. La, Rosa and C. J. Suckling, Org. Biomol. Chem., 2003, $1,1909$.

4 C. L. Gibson, J. K. Huggan, L. Kiefer and C. J. Suckling, Chemistry and Biology of Pteridines and Folates, G. Jansen, and G. J. Peters, (eds), SPS Publications, Heilbronn, 2007, p. 269.

5 C. Flamme, D. Johnson, D. McNamara, D. Sherry, P. Toogood and S. VanderWell, 2006, US patent application 2006, 0142312; B. D. Palmer, J. B. Smaill, G. W. Rewcastle, E. M. Dobrusin, A. Kraker, C. W. Moore, R. W. Steinkampf and W. A. Denny, Bioorg. Med. Chem. Lett., 2005, 15, 1931; Z. C. Wu, J. C. Hartnett, L. A. Neilson, R. G. Robinson, S. Fu, S. F. Barnett, D. DefeoJones, R. E. Jones, H. E. Huber, G. D. Hartman and M. T. Bilodeau, Bioorg. Med. Chem. Lett., 2008, 18, 1274.

6 R. J. Perner, Y. G. Gu, C. H. Lee, E. K. Bayburt, J. McKie, K. M. Alexander, K. L. Kohlhaas, C. T. Wismer, J. Mikusa, M. F. Jarvis, E. A. Kowaluk and S. S. Bhagwat, J. Med. Chem., 2003, 46, 5249.

7 M. Martin-Martinez, A. Marty, M. Jourdan, C. Escrieut, E. Archer, R. Gonzalez-Muniz, M. T. Garcia-Lopez, B. Maigret, R. Herranz and D. Fourmy, J. Med. Chem., 2004, 48, 4842; J. J. Chen, N. J. Dewdney, and C. M. Stahl, US patent 2006, 7091347; J. Caballero, M. Fernandez, M. Saavendra and F. D. Gonzalez-Niloa, Bioorg. Med. Chem., 2008, 16, 810; J. A. Wendt, S. D. Deeter, S. E. Bove, C. S. Knauer, R. M. Brooker, C. E. Augelli-Szafran, R. D. Schwartz, J. J. Kinsora and K. S. Kilgore, Bioorg. Med. Chem. Lett., 2007, 17, 5396; S. Storelli, D. Verzijl, J. AlBadie, N. Elders, L. Bosch, H. Timmerman, M. J. Smit, I. J. P. DeEsch and R. Leurs, Archiv der Pharmacie, 2007, 340, 281.

8 A. Gangjee, F. Mavandadi, R. L. Kisliuk, J. J. McGuire and S. F. Queener, J. Med. Chem., 1996, 39, 4563-4568.

9 C. Sanmartin, M. V. Dominguez, L. Cordeau, E. Cubedo, J. GarciaFontcillas, M. Font and J. A. Palop, Archiv der Pharmacie, 2008, 341, 28.

10 H. Huang, D. A. Hutta, H. Hu, R. L. DesJarlais, C. Schubert, I. P. Petrounia, M. A. Chaikin, C. L. Manthy and M. R. Player, Bioorg. Med. Chem. Lett., 2008, 18, 2355.

11 E. C. Taylor and B. Liu, J. Org. Chem., 2003, 68, 9938; A. Gangjee, J. Yang, J. J. McGuire and R. L. Kisliuk, Bioorg. Med. Chem., 2006, 14, 8590; A. Gangjee, W. Li, J. Yang and R. L. Kisliuk, J. Med.Chem., 2008, 51, 68 .

12 L. D. Arnold, D. J. Calderwood, R. W. Dixon, D. N. Johnston, J. S. Kamens, R. Muschauer, P. Rafferty and S. E. Ratsnovsky, Bioorg. Med. Chem. Lett., 2000, 10, 2167; K. J. Moriarty, H. K. Koblish, T. Garrabrant, J. Maisuria, E. Khalil, F. Ali, I. P. Petrounia, C. S. Crysler, A. C. Maroney, D. L. Johnson and R. A. Galemno, Jr., Bioorg. Med. Chem. Lett., 2006, 16, 5778; M. P. Clark, K. M. George, R. G. Bookland, J. Chen, S. K. Laughlin, K. D. Thakur, W. Lee, J. R. Davis, E. J. Cabrera, T. A. Brugel, J. C. VanRens, M. J. Laufersweiler, J. A. Maier, M. P. Sabat, A. Golebiowski, V. Easwaran, M. E. Webster, B. De and G. Zhang, Bioorg. Med. Chem. Lett., 2007, 17, 1250-1253; S. Olgen, Y. G. Isgor and T. Coban, Archiv der Pharmazie, 2008, 341, 113; E. Vanotti, R. Amici, A. Bargioti, J. Berthelesen, R. Bosotti, A. Cialovella, A. Cirla, C. Cristiani, R. D’Alessio, B. Forte, A. Isacchi, K. Martina, M. Meninchincheri, A. Molinari, A. Montagnoli, P. Orsini, A. Pillan, F. Roletto, A. Scolaro, M. Tibolla, B. Valsasina, M. Varasi, D. Volpi and C. Santocanale, J. Med. Chem., 2008, 51, 487; A. Gangjee, O. A. Namjoshi, J. M. Yu, M. H. Ihnat, J. E. Thorpe and L. A. Warnke, Bioorg. Med. Chem., 2008, 16, 5514; Z. W. Cai, D. Wei, G. M. Schroeder, L. A. M. Cornelius, K. Kim, X. T. Chen, R. J. Schmidt, D. K. Williams, J. S. Tokarsi, Y. M. An, J. S. Sack, V. Manne, A. Kamath, Y. P. Zhang, P. Marathe, J. T. Hunt, L. J. Lombardo, J. Fargnoli and R. M. Borzilleri, Bioorg. Med. Chem. Lett., 2008, 18, 3224.

13 L. B. Townsend, and J. C. Drach, 2002 US patent 6342501; C. V. Varaprasad, K. S. Ramasamy, J. L. Girardet, E. Gunic, V. Lai, W. Zhong, H. An and Z. Hong, Bioorg. Chem., 2007, 35, 25; Y.-H. Koh, J. H. Shim, J.-L. Girardet and Z. Hong, Bioorg. Med. Chem. Lett., 2007, 17, 5261.

14 S. Wang, A. Folkes, I. Chuckowree, X. Cockcroft, S. Sohal, W. Miller, J. Milton, S. P. Wren, N. Vicker, P. Depledge, J. Scott, L. Smith, H. Jones,
P. Mistry, R. Faint, D. Thompson and S. Cocks, J. Med. Chem., 2004, 47, 1329 .

15 A. M. Palmer, G. Munch, C. Brehm, P. J. Zimmerman, W. Buhr, M. P. Feth and W. A. Simon, Bioorg. Med. Chem., 2008, 16, 1511.

16 C. Esteve, A. Nueda, J. L. Diaz, J. Beleta, A. Cardenas, E. Lozoya, M. I. Cadavid, M. I. Loza, H. Ryder and B. Vidal, Bioorg. Med. Chem. Lett., 2006, 16, 3642; R. J. Gillespie, I. A. Cliffe, C. E. Dawson, C. T. Dourish, S. Gaur, A. M. Jourdan, A. R. Knight, J. Lerpiniere, A. Misra, R. M. Pratt, J. Roffey, G. C. Stratton, R. Upton, S. M. Weiss and D. S. Williamson, Bioorg. Med. Chem. Lett., 2008, 18, 2924.

17 A. Gangjee, R. Devraj, J. J. McGuire, R. L. Kisliuk, S. F. Queener and L. R. Barrows, J. Med. Chem., 1994, 37, 1169; A. Gangjee, Y. Zeng, J. J. McGuire and R. L. Kisliuk, J. Med. Chem., 2005, 48, 5329.

18 F. Wahid, C. Monneret and D. Dauzonne, Chem, Pharm. Bull., 1999, 47, 156.

19 Y. Miyazaki, Y. Maeda, H. Sato, M. Nakano and G. W. Mellor, Bioorg. Med. Chem. Lett., 2008, 18, 1967; E. F. DiMauro, J. Newcombe, J. J. Nunes, J. E. Bemis, C. Boucher, J. L. Buchanan, W. H. Buckner, A. Cheng, T. Faust, F. Hseih, X. Huang, J. H. Lee, T. L. Marshall, M. W. Martin, D. C. McGowan, S. Schneider, S. M. Turci, R. D. White and X. Zhu, Bioorg. Med. Chem. Lett., 2007, 17, 2305.

20 F. Amblard, V. Aucagne, P. Guenot, R. F. Schinazi and L. A. Agrofolio, Bioorg. Med. Chem. Lett., 2005, 13, 1239-1248; G. Andrei, R. Sienart, C. McGuigan, E. DeClerq, J. Balzanini and R. Snoek, Antimicrob. Agents Chemother., 2005, 49, 1081.

21 A. Gangjee, F. Mavanandi, R. L. Kisliuk, J. J. McGuire and S. F. Queener, J. Med. Chem., 1996, 39, 4562; A. Gangjee, H. D. Jain, J. Phan, X. Song, J. J. McGuire and R. L. Kisliuk, J. Med. Chem., 2006, 49, 1055.

22 S. Ding, N. S. Gray, Q. Ding, X. Wu and P. G. Schultz, J. Comb. Chem., 2002, 4, 183.

23 L. G. J. Hammarström, D. B. Smith and F. X. Talamás, Tetrahedron Lett., 2007, 48, 2823.

24 D. G. Gourley, A. W. Schüttelkopf, G. A. Leonard, J. Luba, L. W. Hardy, S. M. Beverley and W. N. Hunter, Nat. Struct. Biol., 2001, 8, 521; A. Shuttelkopf, L. W. Hardy, S. M. Beverley and W. N. Hunter, J. Mol. Biol., 2005, 352, 105; A. Cavazzuti, G. Paglietti, W. N. Hunter, F. Gamarro, S. Piras, M. Loriga, S. Allecca, P. Corona, K. McLuskey, L. Tulloch, F. Gibellini, S. Ferrari and M. P. Costi, Proc. Natl. Acad. Sci. U. S. A., 2008, 105, 1448.

25 J. Wu, L. Wang, R. Fathi and Z. Yang, Tetrahedron Lett., 2002, 43, 4395.

26 S. Cacchi, G. Fabrizi, L. M. Parisi and R. Bernini, Synlett, 2004, 287.

27 E. C. Western and K. H. Shaughnessy, J. Org. Chem., 2005, 70, 6378.

28 G. A. Molander and B. Biolatto, Org. Lett., 2002, 4, 107; R. A. Batey and T. D. Quach, Tetrahedron Lett., 2001, 42, 9000; G. A. Molander and C. R. Bernardi, J. Org. Chem., 2002, 68, 8424.

29 (a) J. Adcock, C. L. Gibson, J. K. Huggan, and C. J. Suckling, Manuscript in preparation; (b) Chemistry and Biology of Pteridines and Folates, ed. G. Jansen and G. J. Peters, SPS Publications, Heilbronn, 2007, p. 269.

30 D. Guiney, C. L. Gibson and C. J. Suckling, Org. Biomol. Chem., 2003, 1, 664; C. L. Gibson, K. Ohta, K. Paulini and C. J. Suckling, J. Chem. Soc., Perkin Trans. 1, 1998, 3025.

31 N. R. Mohamed, M. M. T. ElSaidi, Y. M. Ali and M. H. Elnagdi, Bioorg. Med. Chem., 2007, 15, 6227.

32 M. Melguizo, M. Nogueras and A. Sanchez, Heterocycles, 1991, 32, 1719.

33 E. C. Taylor and B. Liu, Tetrahedron Lett., 1999, 40, 4023; E. C. Taylor and B. Liu, J. Org. Chem., 2003, 68, 9938.

34 L. M. Gayo and M. J. Suto, Tetrahedron Lett., 1997, 38, 211; D. Obrecht, C. Abrecht, A. Grieder and J. M. Villalgordo, Helv. Chim. Acta, 1997, 80, 65 .

35 W. Adam, J. Bialas and L. Hadjiaragopolou, Chem. Ber., 1991, 124, 2377.

36 B. Suzuki, M. B. Yamamoto, S. Shimura, K.-I. Miyamoto, K. Yamamoto and H. Sawanishi, Chem. Pharm. Bull., 2002, 50, 1163; T. Nagamatsu and H. Yamasaki, J. Chem. Soc., Chem. Commun., 1995, 2041; J. Shimada, T. Kuroda and F. Suzuki, J. Heterocyclic Chem., 1993, 30, 241.

37 E. C. Taylor, O. Vogl and C. Cheng, J. Am. Chem. Soc., 1959, 81, 2442.

38 K. Avasthi, T. Chandra and D. Bhakuni, Indian J. Chem. A., 1995, 34, 173. 
39 A. Cavazzuti, G. Paglietti, W. N. Hunter, F. Gamarro, S. Piras, M. Loriga, S. Alleca, P. Corona, K. McLuskey, L. Tulloch, F. Gibellini, S. Ferrari and M. P. Costi, Proc. Natl. Acad. Sci. U. S. A., 2008, 105, 1448.

40 B. Raz, M. Iten, Y. Grether-Buhler, R. Kaminsky and R. Brun, Acta Tropica, 1997, 68, 139.

41 J. O'Brian, I. Wilson, T. Orton and F. Pognan, European Journal of Biochemistry, 2000, 267, 5421.

42 W. C. Still, M. Kahn and A. Mitra, J. Org. Chem., 1978, 43, 2923.
43 A. Gangjee, A. Vidwans, E. Elzein, J. J. McGuire, S. F. Queener and R. L. Kisliuk, J. Med. Chem., 2001, 44, 1993.

44 J. O'Brien, I. Wilson, T. Orton and F. Pognan, Eur. J. Biochem., 2000, 267, 5421; K. B. Jonsson, A. Frost, R. Larsson, S. Llunghall and O. Ljunggren, Calcified Tissue International, 1997, 60, 30; S. A. Back, R. Khan, X. Gan, P. A. Rosenburg and J. J. Volpe, Neuroscience Methods, 1999, 91, 47.

45 G. M. Sheldrick, SHELXL-97 a program for crystal structure refinement, University of Göttingen, Göttingen, Germany, 2007. 